\title{
Control of Subduction Zone Age and Size on Flat Slab Subduction
}

\author{
Wouter Pieter Schellart*t \\ Department of Earth Sciences, Vrije Universiteit Amsterdam, Amsterdam, Netherlands
}

\section{OPEN ACCESS}

Edited by:

Jeroen Van Hunen,

Durham University, United Kingdom

Reviewed by:

Claire Currie,

University of Alberta, Canada Bernhard Maximilian Steinberger,

German Research Centre

for Geosciences, Helmholtz Centre

Potsdam, Germany

*Correspondence:

Wouter Pieter Schellart

w.p.schellart@vu.nl

tORCID:

Wouter Pieter Schellart

orcid.org/0000-0002-9802-0143

Specialty section:

This article was submitted to

Solid Earth Geophysics,

a section of the journal

Frontiers in Earth Science

Received: 16 October 2019

Accepted: 27 January 2020

Published: 19 February 2020

Citation:

Schellart WP (2020) Control of Subduction Zone Age and Size on

Flat Slab Subduction.

Front. Earth Sci. 8:26.

doi: 10.3389/feart.2020.00026
Flat slab subduction is an enigmatic style of subduction where the slab attains a horizontal orientation for up to several hundred kilometers below the base of the overriding plate. It has been linked to the subduction of buoyant aseismic ridges or plateaus, but the spatial correlation is problematic, as there are subducting aseismic ridges and plateaus that do not produce a flat slab, most notably in the Western Pacific, and there are flat slabs without an aseismic ridge or plateau. In this paper an alternative hypothesis is investigated which poses that flat slab subduction is associated with subduction zones that are both old (active for a long time) and wide (large trenchparallel extent). A global subduction zone compilation is presented showing that flat slabs preferentially occur at old (> 80-100 Myr) and wide ( $\geq \sim 6000 \mathrm{~km})$ subduction zones. This is explained by the tendency for wide subduction zones to decrease their dip angle in the uppermost mantle with progressive time, especially in the center. A set of numerical subduction models confirms this behavior, showing that only the central parts of wide slabs progressively reduce their slab dip, such that slab flattening, and ultimately flat slab subduction, can occur. The models further show that a progressive decrease in slab dip angle for wide slabs leads to increased vertical deviatoric tensional stresses at the top surface of the slab (mantle wedge suction), facilitating flat slab subduction, while narrow slabs retain steep dip angles and low vertical deviatoric tensional stresses. The results provide a potential explanation why present-day flat slabs only occur in the Eastern Pacific, as only here subduction zones were old and wide enough to initiate flat slab subduction, and why Laramide flat slab subduction and South China flat slab subduction were possible in the geological past.

Keywords: subduction, flat slab, suction, mantle wedge, slab dip, geodynamics, numerical model, aseismic ridge

\section{INTRODUCTION}

The cross-sectional geometry of upper mantle slabs varies considerably on Earth, with variations in slab dip angle, bending curvature and potential deflection of the slab in the mantle transition zone (e.g., Jarrard, 1986; Lallemand et al., 2005). For most active subduction zones on Earth, the uppermost $\sim 200 \mathrm{~km}$ of the slab is defined by one convex-upward slab hinge located close to the trench (Figures 1A,B) (e.g., Kuril-Kamchatka, Izu-Bonin-Mariana, Sunda, Tonga-KermadecHikurangi, New Hebrides). Some subduction segments, however, show two or three slab hinges in the uppermost $200 \mathrm{~km}$. The former generally has a very gentle, convex upward, slab hinge near the trench and a second, more pronounced, convex upward hinge several hundred kilometers downdip, with a very low angle slab segment in between (Figure 1C) (e.g., Alaska, Nankai, Cascadia). The 
latter, with three slab hinges, has one convex-upward hinge near the trench, one concave upward hinge that marks the start of a flat slab segment dipping $\leq 10^{\circ}$, and one convex-upward hinge that marks the end of the flat slab segment (Figure 1D). It is this subduction geometry, with three slab hinges that is most enigmatic and that is the subject of this study. In this contribution, only the subduction geometry with three slab hinges will be referred to as flat slab subduction. There are only a few current cases of such flat slab subduction, including central Chile, southern Peru, central Peru and Mexico, as has been discussed recently (Manea et al., 2017) and as can be seen in global slab models (e.g., Hayes et al., 2012). Several examples have also been proposed for the geological past, such as western North America, Central Andes and South China (Henderson et al., 1984; Li and Li, 2007; Ramos and Folguera, 2009).

The origin of flat slab subduction remains enigmatic. Previous work proposed that flat slabs occur through subduction of buoyant ridges or plateaus such as the Juan Fernandez Ridge and Nazca Ridge at the South American subduction zone (e.g., Pilger, 1981; Gutscher et al., 2000; van Hunen et al., 2002). But the spatial correlation between ridge/plateau subduction and flat slab subduction has many exceptions, with regions of aseismic ridge subduction lacking flat slab subduction (e.g., Tonga with Louisville Ridge, New Hebrides with d'Entrecasteaux Ridge, Mariana with Marcus-Necker Ridge, Kamchatka with Emperor Ridge) and some flat slab subduction segments lacking an aseismic ridge/plateau (e.g., Mexico) (Skinner and Clayton, 2011, 2013; Manea et al., 2017). Others have proposed that flat slab subduction might result from forced trench retreat (e.g., van Hunen et al., 2004; Schepers et al., 2017), strong suction forces in the mantle wedge (e.g., Tovish et al., 1978), or slab-plume interaction (e.g., Betts et al., 2009). The latter mechanism has not generally been applied to Cenozoic examples of flat slab subduction, and recent geodynamic models of slabplume interaction for present-day Earth-like settings indicate that plumes generally do not affect slab geometry as their upward buoyancy flux can be more than two orders of magnitude smaller than the downward slab buoyancy flux (Mériaux et al., 2016). Wedge suction forces are generally considered to play a role in enhancing flat slab subduction (Tovish et al., 1978; van Hunen et al., 2004), but the question is, what might enhance wedge suction? A number of recent modeling works indicate that a relatively thick or far-field cratonic overriding plate will enhance wedge suction and thus facilitate flat slab subduction (Manea et al., 2012; O’Driscoll et al., 2012; Taramón et al., 2015). Forced trench retreat can also reproduce flat slab subduction in geodynamic models (van Hunen et al., 2004), but this forcing is generally externally imposed (mostly as a velocity boundary condition on the overriding plate) and so the question remains what the source of this forcing is and if sufficient forcing can arise in a buoyancy-driven geodynamic environment in nature (and model).

A number of relatively recent works argue that flat slab subduction requires a combination of physical ingredients. Proposed combinations include forced trench retreat and enhanced suction due to a thick cratonic overriding plate (Manea et al., 2012), buoyant plateau subduction with forced trench

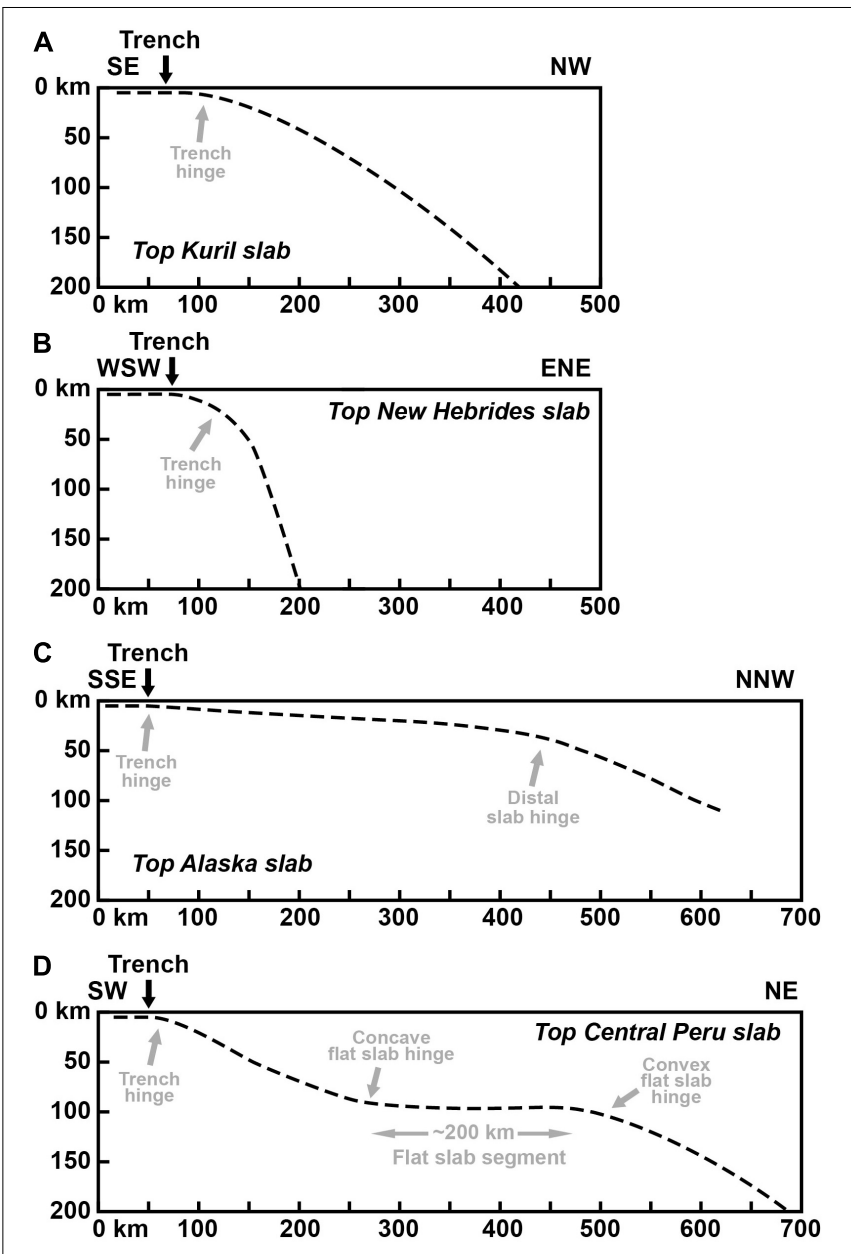

FIGURE 1 | Variability in geometry and dip angle of the uppermost $\sim 200 \mathrm{~km}$ of slabs in nature, as shown by four examples. (A) The southern Kuril slab segment as an example of normal subduction with one convex-upward slab hinge and a normal slab dip angle [geometry derived from Slab1.0 model (Hayes et al., 2012)]. (B) The southern New Hebrides slab segment as an example of normal subduction with one convex-upward slab hinge and a steep slab dip angle [geometry from Slab1.0 model (Hayes et al., 2012)]. (C) The Alaska slab segment as an example of unusual subduction with two convex-upward slab hinges and a low-dip-angle slab segment in between [geometry derived from Ohta et al. (2006)]. (D) The Central Peru slab segment as an example of unusual subduction with two convex-upward slab hinges (trench hinge and convex flat slab hinge) and one concave upward slab hinge (concave flat slab hinge) in between [geometry derived from Phillips and Clayton (2014)]. A (sub)horizontal slab segment is located between the concave and convex flat slab hinges. It is only this slab geometry with three hinges that is referred to as flat slab subduction in this work and that is the focus of this study. Note that all images show the geometry of the top of the slab.

and plate motion (Liu and Currie, 2016), buoyant ridge/plateau subduction, enhanced suction, young oceanic plate subduction, and forced trench and plate motion ( $\mathrm{Hu}$ et al., 2016), or ridge/plateau subduction, suction and forced trench retreat (van Hunen et al., 2004; Antonijevic et al., 2015).

Here I build on these earlier findings and investigate the hypothesis that flat slab subduction (with three slab hinges as 
in Figure 1D) preferentially occurs at old subduction zones (those that have been active for a long time) that are very wide (large trench-parallel extent), because long-term subduction facilitates lower mantle slab penetration, which - through deepmantle return flow - forces trenchward overriding plate motion, overriding plate thickening, upper mantle slab dip reduction and trench retreat (Schellart, 2017), with trench retreat being slow due to the wide-slab setting (Schellart et al., 2007), while wide-slab subduction enhances wedge suction, especially in the center (Dvorkin et al., 1993). A compilation from geological data of subduction zones in nature is presented, as well as results from buoyancy-driven geodynamic subduction models, that both provide support for the hypothesis that subduction zone width and age play an important role in flat slab subduction.

\section{MATERIALS AND METHODS}

\section{Data Sources for Subduction Zones in Nature}

A major compilation of subduction zone age and size of the active subduction zones on Earth has been constructed, either with or without flat slab subduction, as well as a number of subduction settings from the geological past for which flat slab subduction has been reported (Figure 2). The data sources that have been used are listed in Tables 1, 2, and consist of previous works on the geological and tectonic evolution of subduction zones. Table 1 lists those subduction zones that have a presentday flat slab or a flat slab in the geological past as defined in Figure 1D in the paper (i.e., a subduction zone with a trench hinge and two flat slab hinges). Table 2 lists those subduction zones that have no reported flat slab and subduction segments of relatively large subduction zones for which that particular segment itself currently has no flat slab. For both tables, slab widths are listed. For Table 1 these are the slab widths during (or close to) subduction zone formation and the slab widths at the time when flat slab subduction commenced. For Table 2 these are the slab widths during (or close to) subduction zone formation and the present-day slab widths. All the present-day slab widths have been derived from Schellart et al. (2007). For slab width values during the geological past, a variety of published plate tectonic reconstructions have been used. Both tables also list the age of the subduction zone (the time of subduction initiation), while Table 1 also lists the time of flat slab inception and the subduction zone age at the time of flat slab inception. Details and justifications for data selection and uncertainties associated with the data are listed in the Appendix.

\section{Numerical Modeling Method}

The hypothesis that flat slab subduction occurs for old and wide subduction zones is tested with geodynamic models of long-lived, buoyancy-driven, progressive subduction in which slab width is varied. The models use the Underworld numerical modeling code (Stegman et al., 2006; Moresi et al., 2007) and the model approach is the same as discussed in Schellart (2017). The models are run non-dimensionally and are later scaled to natural values. The reader is referred to the earlier works for
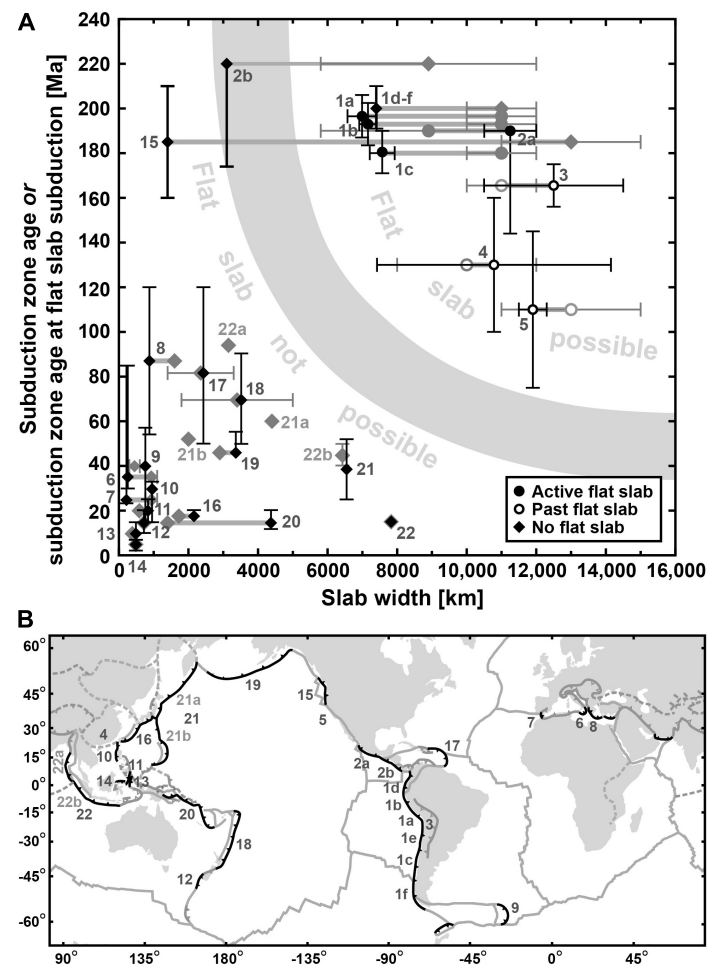

FIGURE 2 | (A) Diagram showing the dependence of flat slab subduction in nature on slab width (trench-parallel extent) and subduction zone age. Diamonds represent subduction zones/segments without a flat slab. Filled circles and white circles with an outline represent subduction zones with a present-day flat slab and flat slab in the geological past, respectively. For the black circles and white circles with black outline subduction zone age and slab width represent the age and width at the time of flat slab inception. For the black diamonds subduction zone age and slab width represents their age and width at present. For the gray circles, white circles with a gray outline and gray diamonds slab width represents the width at subduction initiation. See Appendix and Tables 1, 2 for data choices, justification and uncertainties. Black bars and gray bars are not error bars but indicate range of age estimates and slab width estimates, where data point location represents the average or the best estimate (see Appendix and Tables 1, 2). Thick horizontal gray lines connect subduction initiation data point with present-day subduction zone data point (diamonds) or flat slab subduction initiation data point (circles) of the same subduction zone (segment). Subduction zone data points: 1-South America with 1a-Southern Peru segment (Nazca ridge), 1b-Central Peru segment, 1c-Central Chile segment (Juan Fernandez ridge), 1d-Colombia segment, 1e-Northern Chile segment, 1f-Southern Chile segment; 2-Mexico-Central America with 2a-Mexico segment, 2b-Central America segment; 3-South America (Central Andes segment); 4-South China; 5-Farallon (Laramide segment); 6-Calabria; 7-Gibraltar; 8-Hellenic; 9-Scotia; 10-Manila; 11-Sangihe; 12-Puysegur; 13-Halmahera; 14-North Sulawesi; 15-Cascadia; 16-Nankai-Ryukyu; 17-Lesser Antilles-Puerto Rico; 18-Tonga-Kermadec-Hikurangi; 19-Aleutians-Alaska; 20-Melanesia (New Britain-San Cristobal-New Hebrides); 21-Northwest Pacific

(Kamchatka-Kuril-Japan-Izu-Bonin-Mariana) with 21a-Kamchatka-Kuril-Japan segment, 21b-Izu-Bonin-Mariana segment; 22-Sunda

(Burma-Andaman-Sumatra-Java-Banda) with 22a-Burma-Andaman segment, 22b-Burma-Andaman-Sumatra-Java segment. The light gray zone indicates the approximate location of the boundary separating the domains where flat slab subduction is not possible (lower left) and possible (upper right). Note that for the individual subduction zone segments (1a-f and 2a-b) the entire width of the slab that these segments form part of has been plotted. (B) Map showing the location of those subduction zones and segments plotted in panel (A). 
TABLE 1 | Subduction zones with a flat slab.

\begin{tabular}{|c|c|c|c|c|c|c|c|c|c|}
\hline Subduction zone & $\begin{array}{l}\text { Number in } \\
\text { Figure } 2\end{array}$ & $\begin{array}{c}\text { Slab width } \\
\text { (average) at flat } \\
\text { slab initiation* } \\
\text { [km] }\end{array}$ & $\begin{array}{c}\text { Slab width } \\
\text { (min.-max.) at flat } \\
\text { slab initiation } \\
{[\mathrm{km}]}\end{array}$ & $\begin{array}{c}\text { Distance to } \\
\text { closest slab edge } \\
\text { at flat slab } \\
\text { initiation }^{\wedge}[\mathrm{km}]\end{array}$ & $\begin{array}{c}\text { Slab width } \\
\text { during/close to } \\
\text { subduction zone } \\
\text { formation [km] }\end{array}$ & $\begin{array}{c}\text { Subduction zone } \\
\text { age (best } \\
\text { estimate/average) } \\
{[\mathrm{Ma}]}\end{array}$ & $\begin{array}{l}\text { Subduction zone } \\
\text { age (min.-max.) } \\
\text { [Ma] }\end{array}$ & $\begin{array}{l}\text { Time of flat slab } \\
\text { inception [Ma] }\end{array}$ & $\begin{array}{l}\text { Subduction zone } \\
\text { age at flat slab } \\
\text { initiation }{ }^{\ddagger}[\mathrm{Ma}]\end{array}$ \\
\hline \multicolumn{10}{|c|}{ With present-day flat slab } \\
\hline $\begin{array}{l}\text { South America } \\
\text { (Southern Peru) }\end{array}$ & $1 a$ & $6992^{(1,2)}$ & $6571-7413$ & 2200 & $11,000 \pm 1000^{(2)}$ & 200 (be) & $191-210^{(3-6)}$ & $4^{(7)}$ & 196 \\
\hline $\begin{array}{l}\text { South America (Central } \\
\text { Peru) }\end{array}$ & $1 b$ & $7162^{(1,2)}$ & $6911-7413$ & 1400 & $11,000 \pm 1000^{(2)}$ & 200 (be) & $191-210^{(3-6)}$ & $8^{(7)}$ & 192 \\
\hline $\begin{array}{l}\text { South America (Central } \\
\text { Chile) }\end{array}$ & $1 \mathrm{c}$ & $7570^{(1,2)}$ & $7212-7928$ & 2400 & $11,000 \pm 1000^{(2)}$ & 200 (be) & $191-210^{(3-6)}$ & $20^{(8)}$ & 180 \\
\hline $\begin{array}{l}\text { Mexico-Central } \\
\text { America (Mexico) }\end{array}$ & $2 a$ & $11,250^{(9,10)}$ & $10,500-12,000$ & 2100 & $\begin{array}{c}\sim 5800^{(6)} \text { or } \\
11,000 \pm 1000^{(2)}\end{array}$ & 220 (be) & $\begin{array}{c}174-201^{(11)} \text { or } \\
220^{(12)}\end{array}$ & $30-25^{(13-15)}$ & 190 \\
\hline \multicolumn{10}{|l|}{ With past flat slab } \\
\hline $\begin{array}{l}\text { South America (Central } \\
\text { Andes) }\end{array}$ & 3 & $12,500^{(9,10)}$ & $10,500-14,500$ & 3800 & $11,000 \pm 1000^{(2)}$ & 200 (be) & $191-210^{(3-6)}$ & $35^{(16)}$ & 165 \\
\hline South China ${ }^{+}$ & 4 & $10,784^{(17)}$ & $7421-14,146$ & 3000 & $10,000 \pm 2000^{(17)}$ & $360(a v)$ & $330-390^{(17,18)}$ & $230^{(19)}$ & 130 \\
\hline Farallon\% & 5 & $11,900^{(9,10)}$ & $11,500-12,300$ & $1700-2700$ & $13,000 \pm 2000^{(2)}$ & 185 (av) & $160-210^{(20,21)}$ & $85-65^{(22-24)}$ & $100-120$ \\
\hline
\end{tabular}

*Slab width is based on the average of the estimated minimum and maximum slab width at the time of inception of flat slab subduction. It is derived from tectonic reconstructions presented in Gordon and Jurdy (1986); Collins (2003), Schellart et al. (2007, 2010), Domeier and Torsvik (2014) and Seton et al. (2012). ^ Trench-parallel distance from flat slab segment to closest lateral slab edge at the time of flat slab inception. ${ }^{\dagger}$ Subduction zone age (time of subduction zone initiation) based on the best estimate (be) or average (av) of the estimated minimum and maximum age. ${ }^{+}$Age of the subduction zone at the time of inception of flat slab subduction. ${ }^{\circledR}$ Southern Peru flat slab spatially correlated with the subducting Nazca Ridge (Pilger, 1981; Gutscher et al., 2000). ${ }^{\circledR}$ Central Peru flat slab possibly related to subduction of the Inca plateau (Gutscher et al., 2000). "Central Chil flat sab spatially correlated with the subducting Jun Fernandez Ridge (Pilger. 1981; Gutscher et a. 2000). \# Mexican flat sab, not spatially associated with any ridge or plateau (Skinner and Clayton,

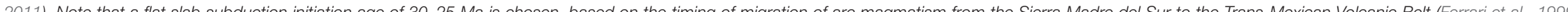
Morán-Zenteno et al. 1999: Kim et al. 2010), and not a younger initiation age of 16-9 Ma proposed more recently (Manea et al., 2017). A consequence of adopting the older age is that the slab width then includes the South American segment and Mexico-Central America segment (and possibly the Baja California segment), because the Nazca and Cocos plates still formed one single plate until 23 Ma (Lonsdale, 2005). \& Central Andes (southern Peru-northernmost Chile) flat slab in the latest Eocene-Oligocene (Ramos and Folguera, 2009). + South China flat slab in the Middle Triassic-Early Jurassic (Li and Li, 2007). \% Farallon flat slab in western North America, thought to be responsible for the Laramide orogeny and eastward migration of the magmatic arc (Dickinson and Snyder, 1978; Henderson et al., 1984). The numbers in between the brackets refer to the following references: 'Schellart et al. (2007), '2 Seton et al. (2012), ${ }^{3}$ Coira et al. (1982), "'Vásquez et al. (2011), ${ }^{5}$ Scheuber et al. (1994), ${ }^{6}$ van der Meer et al. (2018), ${ }^{7}$ Rosenbaum et al. (2005), ${ }^{8}$ Kay and Abbruzz (1996), ${ }^{9}$ Schellart et al. (2010), ${ }^{10}$ Gordon and Jurdy (1986), ${ }^{11}$ Centeno-García (2017). ${ }^{12}$ Boschman et al. (2018) 13 Kim et al. (2010), 14 Morán-Zenteno et al (1999), 15 Ferrari et al. (1999), 16 Ramos and Folguera (2009), ${ }^{17}$ Domeier and Torsvik (2014), ${ }^{18}$ Collins (2003), ${ }^{19}$ Li and Li (2007), ${ }^{20}$ Burchfiel and Davis (1975), ${ }^{21}$ DeCelles (2004), ${ }^{22}$ Henderson et al. (1984), ${ }^{23}$ Liu et al. (2010), ${ }^{24}$ Copeland et al. (2017). 
TABLE 2 | Active subduction zones and active subduction zone segments without a flat slab.

\begin{tabular}{|c|c|c|c|c|c|c|}
\hline Subduction zone & $\begin{array}{l}\text { Number in } \\
\text { Figure } 2\end{array}$ & $\begin{array}{l}\text { Present-day slab } \\
\text { width* [km] }\end{array}$ & $\begin{array}{l}\text { Slab width during/close } \\
\text { to subduction zone } \\
\text { formation }[\mathrm{km}]\end{array}$ & $\begin{array}{c}\text { Subduction zone age } \\
\text { (best estimate/average) } \\
\text { [Ma] }\end{array}$ & $\begin{array}{c}\text { Subduction zone } \\
\text { age (lower limit) } \\
\text { [Ma] }\end{array}$ & $\begin{array}{c}\text { Subduction zone } \\
\text { age (upper limit) } \\
\text { [Ma] }\end{array}$ \\
\hline \multicolumn{7}{|l|}{ Subduction zones } \\
\hline Calabria & 6 & 300 & $800^{(1)}$ or $1100^{(2,3)}$ & 35 (be) & $30^{(2,3)}$ & $85^{(1)}$ \\
\hline Gibraltar & 7 & 250 & $800^{(1)}$ or $1100^{(2,3)}$ & 25 (be) & $23^{(4)}$ & $85^{(1)}$ \\
\hline Hellenic & 8 & 900 & $1600^{(5)}$ & 87 (av) & $54^{(6)}$ & $120^{(7)}$ \\
\hline Scotia & 9 & 800 & $\sim 300^{(8)}$ or $\sim 600^{(9)}$ & $50^{(9,10)}(\mathrm{be})$ & $15^{\wedge(11)}$ & $57^{(8)}$ \\
\hline Manila & 10 & 1000 & $\sim 1000^{(12)}$ & $30^{(12)}(\mathrm{be})$ & $15^{(13)}$ & $33^{(13)}$ \\
\hline Sangihe & 11 & 850 & $600^{(14)}$ & $20(a v)$ & $15^{(14)}$ & $25^{(14)}$ \\
\hline Puysegur & 12 & 750 & $750^{(15)}$ & $15(\mathrm{av})$ & $10^{(16)}$ & $20^{(15)}$ \\
\hline Halmahera & 13 & 500 & $400^{(14)}$ & $10^{(14)}(\mathrm{be})$ & $7^{(14)}$ & $15^{(14)}$ \\
\hline North Sulawesi & 14 & 500 & $500^{(17)}$ & $5^{(14)}(\mathrm{be})$ & $2^{(14)}$ & $7^{(14)}$ \\
\hline Cascadia & 15 & 1400 & $13,000 \pm 2000^{(18)}$ & $185(\mathrm{av})$ & $160^{(19)}$ & $210^{(20)}$ \\
\hline Nankai-Ryukyu & 16 & 2200 & $\sim 1600^{(12)}$ & $18^{(12)}(\mathrm{be})$ & & $20^{(17)}$ \\
\hline Lesser Antilles-Puerto Rico & 17 & 2450 & $\sim 1400^{(21)}$ or $3300^{(22)}$ & $85(\mathrm{av})$ & $50^{(21)}$ & $120^{(22)}$ \\
\hline Tonga-Kermadec-Hikurangi & 18 & 3550 & $\sim 1800^{(23)}$ or $\sim 5000^{(15)}$ & $70(\mathrm{av})$ & $50^{(23)}$ & $90^{(15,24)}$ \\
\hline Aleutians-Alaska & 19 & 3400 & $2900^{(25)}$ & $46^{(26)}$ & & $55^{(25)}$ \\
\hline Melanesia ${ }^{\dagger}$ & 20 & 4400 & $1400^{(15)}$ & $15^{(17)}(\mathrm{be})$ & $12^{(24)}$ & $15^{(17,15)}$ \\
\hline Northwest Pacific ${ }^{\ddagger}$ & 21 & 6550 & & $39(\mathrm{av})$ & $25^{(30)}$ & $52^{(29)}$ \\
\hline Kamchatka-Japan segment & $21 \mathrm{a}$ & & $4400^{(27)}$ & $60^{(27)}(\mathrm{be})$ & & \\
\hline Izu-Mariana segment & $21 b$ & & $\sim 2000^{(28)}$ & $52^{(29)}(\mathrm{be})$ & $48^{(31)}$ & $52^{(29)}$ \\
\hline Sunda & 22 & 7850 & & 15 (be) & & \\
\hline Burma-Andaman (Bu-Ad) & $22 a$ & & 3150 & $94 ?^{(32)}(\mathrm{be})$ & & \\
\hline $\begin{array}{l}\text { Bu-Ad + Sumatra-Java } \\
(\text { Su-JV) }\end{array}$ & $22 b$ & & $3150+3300$ & $45^{(14)}(\mathrm{av})$ & $40^{(14)}$ & $50^{(14)}$ \\
\hline$B u-A d-S u-J v+$ Banda & 22 & & $6450+1400$ & $15^{(33)}(\mathrm{be})$ & & \\
\hline \multicolumn{7}{|l|}{ Subduction zone segments } \\
\hline \multicolumn{7}{|l|}{ South America } \\
\hline Colombia & $1 d$ & 7400 & $11,000 \pm 1000^{(18)}$ & $200^{(34-36,10)}(\mathrm{be})$ & $191^{(35)}$ & $210^{(35)}$ \\
\hline Northern Chile & $1 e$ & 7400 & $11,000 \pm 1000^{(18)}$ & $200^{(34-36,10)}(\mathrm{be})$ & $191^{(35)}$ & $210^{(35)}$ \\
\hline Southern Chile & $1 f$ & 7400 & $11,000 \pm 1000^{(18)}$ & $200^{(34-36,10)}(\mathrm{be})$ & $191^{(35)}$ & $210^{(35)}$ \\
\hline \multicolumn{7}{|l|}{ Mexico-Central America } \\
\hline Central America & $2 b$ & 3100 & $5800^{(10)} / 11,000 \pm 1000^{(18)}$ & 220 (be) & $174-201^{(37)}$ & $220^{(38)}$ \\
\hline
\end{tabular}

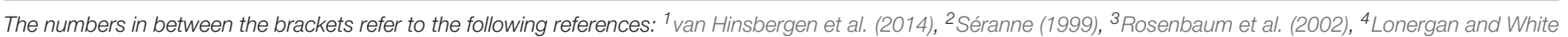

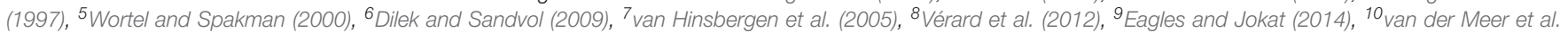

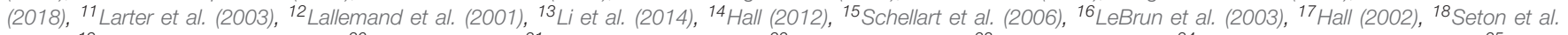

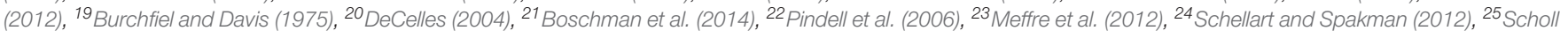

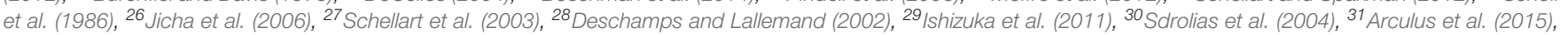

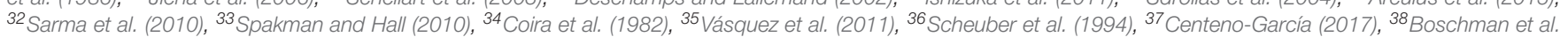

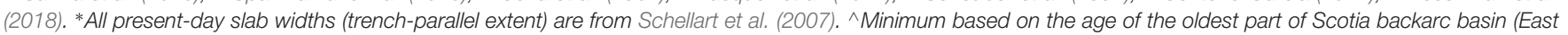
Scotia Sea) bordering the active Scotia arc. ${ }^{\dagger}$ Melanesia: New Britain-San Cristobal-New Hebrides. ${ }^{\ddagger}$ Northwest Pacific: Kamchatka-Kuril-Japan-Izu-Bonin-Mariana.

details on the numerical method and approach. The model setup involves buoyancy-driven subduction of a higher-density, viscously stratified, subducting plate below an overriding plate into a lower density, lower viscosity, stratified mantle that extends down to the core-mantle boundary (Figure 3). Each model has free-slip conditions along all its boundaries and starts with a short, 206-km-long slab perturbation dipping at $29^{\circ}$ that triggers buoyancy-driven subduction. The model domain is $10,000 \mathrm{~km}$ long and $2900 \mathrm{~km}$ deep. Four models are presented that are all exactly the same except for their subduction zone width $(W)$ and box width $(B W)$ : a narrow slab model (W600 with $W=600 \mathrm{~km}$, $B W=4000 \mathrm{~km}$ ), an intermediate-width slab model (W2000 with $W=2000 \mathrm{~km}, B W=6000 \mathrm{~km}$ ), a wide slab model (W6000 with $W=6000 \mathrm{~km}, B W=12,000 \mathrm{~km}$ ), and a very wide slab model
(W-infinite, a model with a $2 \mathrm{D}$ spatial set-up, so $W=$ infinite, $B W=$ infinite). The models do not contain lateral side plates, assuming that the transform faults along the sides of the plates are very weak. Furthermore, the trailing edges of the plates are free, mimicking spreading ridges, offering minimal resistance to lateral motion, following earlier works on free subduction (e.g., Kincaid and Olson, 1987; Chen et al., 2016).

The subducting plate has a homogeneous density that is $60 \mathrm{~kg} / \mathrm{m}^{3}$ higher than that of the sub-lithospheric mantle, and is viscously stratified into three layers, including a viscoplastic top layer with a von Mises rheology to allow for decoupling of the subducting plate from the top surface, a high-viscosity Newtonian central layer and a low-viscosity Newtonian bottom layer (Figure 3). The effective viscosity averaged over the 


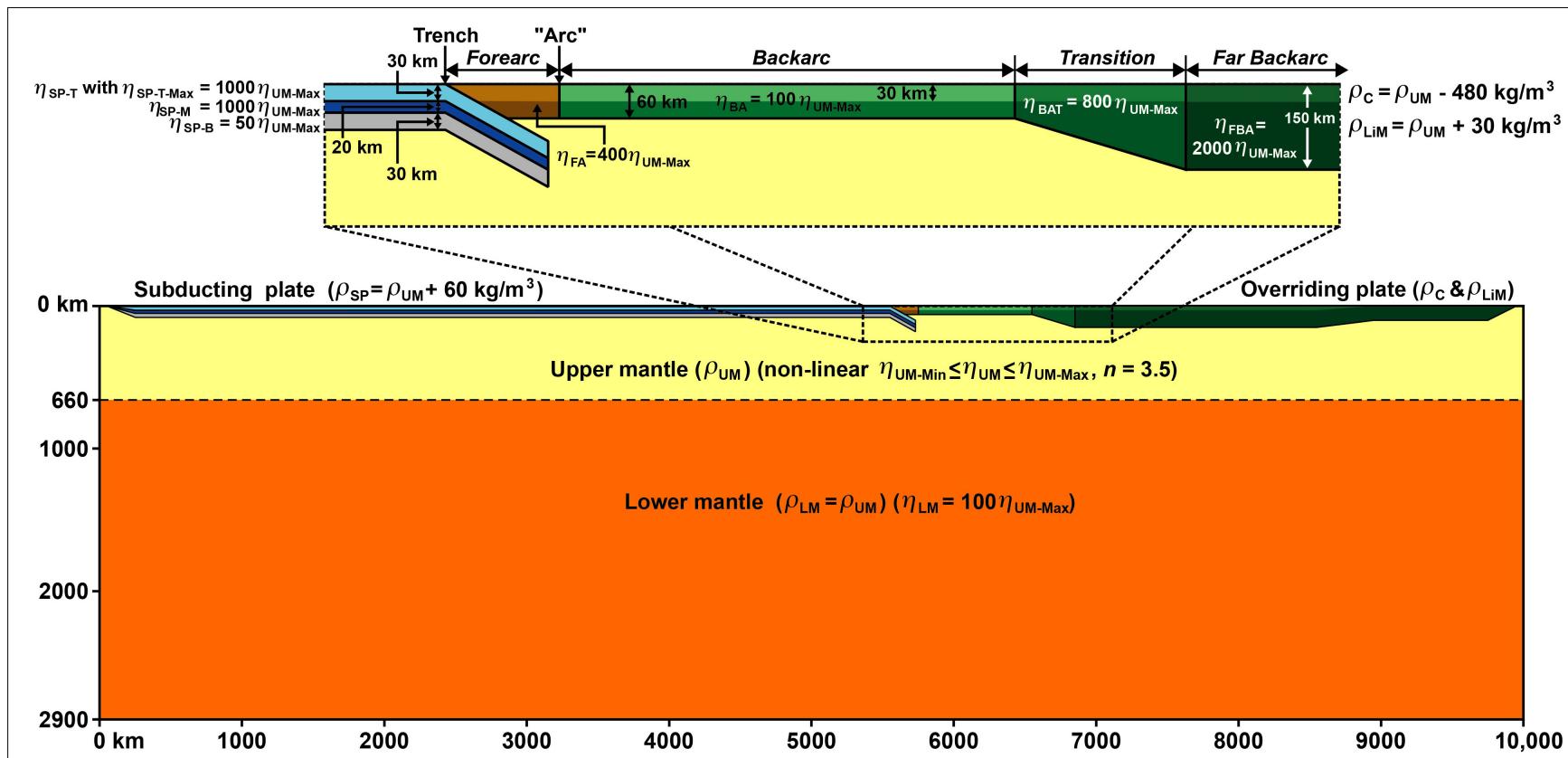

FIGURE 3 | Cross-section through the center of the numerical domain showing the model set-up to investigate buoyancy-driven time-evolving subduction in a very large domain with a layered whole mantle reservoir. The four models reported in the paper are all the same in cross-section but differ in trench-parallel extent with a different box width $(B W)$ and slab width $(W)$ : the narrow slab model with $B W=4000 \mathrm{~km}$ and $W=600 \mathrm{~km}$; the intermediate- width slab model with $B W=6000 \mathrm{~km}$ and $W=2000 \mathrm{~km}$; the wide slab model with $B W=12,000 \mathrm{~km}$ and $W=6000 \mathrm{~km}$; and the very wide slab model with $B W=$ infinite and $W=$ infinite $(2 D$ model set-up). The geodynamic models include a layered negatively buoyant subducting plate with three layers with different viscosity (top, middle and bottom) and a layered overriding plate with two layers with the same viscosity but different density (crustal layer and lithospheric mantle layer). $\eta_{S P}-\mathrm{T}=$ subducting plate top layer viscosity, $\eta_{S P}-T-M a x=$ subducting plate top layer maximum viscosity, $\eta_{S P}-\mathrm{M}=$ subducting plate middle layer viscosity, $\eta_{S P}-\mathrm{B}=$ subducting plate bottom layer viscosity, $\eta_{F A}=$ forearc viscosity, $\eta_{\mathrm{BA}}=$ backarc viscosity, $\eta_{\mathrm{BAT}}=$ backarc transition zone viscosity, $\eta_{\mathrm{FBA}}=$ far backarc viscosity, $\eta_{\mathrm{AM}}=$ sub-lithospheric upper mantle

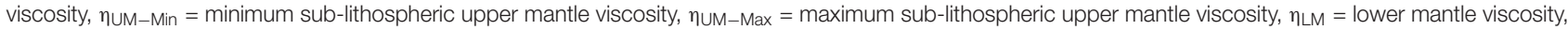
$\rho \cup \mathrm{M}=$ sub-lithospheric upper mantle density, $\rho_{\mathrm{LM}}=$ lower mantle density, $\rho_{\mathrm{SP}}=$ subducting plate density, $\rho_{\mathrm{C}}=\mathrm{continental}$ crustal density, and $\rho_{\mathrm{Li}} \mathrm{M}=\mathrm{continental}$ lithospheric mantle density. All the box boundaries have a free-slip condition.

thickness of the slab falls within the range 270-640 $\eta_{U M}-$ Max (with $\eta_{U M-M a x}$ being the maximum sub-lithospheric upper mantle viscosity), which is very comparable to viscosity estimates from earlier works, such as Ribe (2010) with an estimated slab/upper mantle viscosity ratio of 140-510, and Schellart (2008) with an estimated ratio of 100-700. The overriding plate has several lateral domains with each domain having a constant viscosity. It further has a vertical density stratification with a $30-\mathrm{km}$-thick top layer with a density that is $480 \mathrm{~kg} / \mathrm{m}^{3}$ less than that of the sub-lithospheric upper mantle, mimicking the density contrast between continental crust and sub-lithospheric upper mantle, while the density of the lithospheric mantle is $30 \mathrm{~kg} / \mathrm{m}^{3}$ higher, mimicking continental lithospheric mantle with a density that is moderately higher than that of the sublithospheric mantle.

The models include a sub-lithospheric upper mantle domain with a non-linear stress-dependent viscosity $\eta_{U M}$ down to a depth of $660 \mathrm{~km}$, with a stress exponent $n=3.5$ (Mackwell et al., 1990), a minimum viscosity $\eta_{U M}-M i n$ and maximum viscosity $\eta_{U M-M a x}$, such that $\eta_{U M-M i n}=0.1 \eta_{U M-M a x}$. The variation in sub-lithospheric upper mantle viscosity is therefore limited to one order of magnitude to facilitate reasonable convergence rates in the numerical calculations and to ensure that the scaled time of individual time steps does not drop significantly below the average scaled time. The dimensionalized $\eta_{U M-M i n}=5 \times 10^{19} \mathrm{~Pa} s$ and $\eta_{U M-M a x}=5 \times 10^{20} \mathrm{~Pa}$ s. Such values are within the estimated range of values for the sub-lithospheric upper mantle $\left(10^{19}-10^{21} \mathrm{~Pa} s\right)$ in nature (Artyushkov, 1983; Ranalli, 1995). Note, however, that uncertainty in mantle viscosity values in nature directly affect dimensionalized velocity values in the models.

The $2240 \mathrm{~km}$ thick lower mantle domain has a Newtonian viscosity $\eta_{L M}=100 \eta_{U M}-$ Max. As such, a minimum viscosity jump of a factor of $10^{2}$ was applied between the upper and lower mantle. This viscosity step implementation represents all the effects of the $660 \mathrm{~km}$ discontinuity (viscosity changes, density changes, phase transitions) and captures the discontinuity's geodynamic essence through reducing the slab velocity in the lower mantle, as implied by earlier studies on mineral physics and phase transitions in the deep mantle (Torii and Yoshioka, 2007; Ganguly et al., 2009). The choice for this simple implementation is further supported by results from recent subduction modeling, which show that, unless a complete treatment of compositional layers and phase transitions is implemented, large-scale deformation of slabs is better approximated by a model with no phase transitions rather than including an incomplete approximation that over-predicts slab folding (Arredondo and Billen, 2016). 
The isothermal conditions in the model, and thereby the absence of slab warming, will not affect the slab morphology, slab viscosity and slab-mantle density contrast in the upper mantle significantly due to the relatively rapid rate of subduction (up to $7.5 \mathrm{~cm} \mathrm{yr}^{-1}$ ) and the slow rate of conductive slab warming. Lower mantle slab warming is likely more significant, producing a weaker lower mantle slab, which would thereby likely result in stronger slab folding and tighter slab folds. However, the density contrast of the lower mantle folded slab pile is not significantly affected, because it sinks as a whole and includes the entrained mantle material enclosed within the folds. Considering that warming of the folded slab segment coincides with the cooling of the entrained ambient mantle in the folds (Schellart, 2017), the thermal buoyancy contrast between folded slab pile and ambient mantle does not diminish and disappear on a timescale representing the duration of the numerical models. Therefore, the driving mechanism of the lower mantle slab is not significantly affected.

The model resolution in cross-section is 512 (horizontal) $\times 192$ (vertical) elements with 20 particles per element. A mesh refinement has been implemented such that a $3,000 \mathrm{~km}$ (length) by $290 \mathrm{~km}$ (depth) domain around the subduction zone has a maximum resolution with cells that are $9.8 \mathrm{~km}$ long and $7.6 \mathrm{~km}$ deep. This spatial refinement is required for properly resolving the subduction zone interface. The model resolution in the trench-parallel direction is 48 (W600), 80 (W2000), and 160 (W6000) elements. The models with a 3D spatial set-up were run on the Australian national supercomputer (Raijin) using 240-496 cores and individual models took between 3 months (W600) and more than 2 years (W6000) to complete, the latter model requiring more than 90 restarts to complete a total of more than 5000 time steps (with one time step scaling to, on average, $\sim 0.04 \mathrm{Myr}$, so about 40,000 years). Considering the large amount of time and computational resources required to complete these models, it has not been possible to do an extensive parametric investigation other than investigating the influence of slab width. A detailed parametric study is beyond the scope of this work but is part of future studies using models with a 2D spatial set-up, in which the effect of various parameters and boundary conditions on flat slab subduction are investigated, including the subducting plate thickness, subducting plate viscosity, overriding plate viscosity, viscous stratification of the sub-lithospheric mantle, temperature-dependent viscosity and temperature-dependent density, as well as free-slip, no-slip and periodic boundary conditions.

The numerical models use Cartesian geometry. It could be conceived that the usage of (more realistic) spherical geometry would facilitate the formation of flat slabs, especially for wide slabs, because the reduction in spherical surface area with increasing depth requires a sinking slab to accommodate horizontal shortening strains and compressive stresses during progressive sinking, while the total required horizontal shortening increases linearly with slab width. The slab resistance to such strains and the associated in-plane stress arching would provide an additional lifting force to the slab that would promote slab flattening. However, the slab strain magnitude associated with the subduction of a spherical cap in spherical geometry (in contrast to a flat plate in Cartesian geometry which lacks such strain) is independent of the width of the slab, as it merely depends on the vertical sinking distance (with respect to the surface) and the radius of the sphere. Furthermore, it can be shown that strain rates in nature associated with such strains are relatively low. For example, if one considers a subducting plate that sinks from the surface down to $100 \mathrm{~km}$ depth at a vertical sinking rate of $5 \mathrm{~cm} / \mathrm{yr}$, this would amount to a trench-parallel shortening strain and strain rate of $\sim 0.016$ and $\sim 2.5 \times 10^{-16} \mathrm{~s}^{-1}$, respectively, due to the decreased radial distance to the Earth's center and the associated reduction in trench-parallel line length. If we compare such a shortening strain rate with strain rates within subducting plates near the trench in nature resulting from plate convergence and bending, which reach values up to $\sim 10^{-14} \mathrm{~s}^{-1}$ (e.g., Kreemer et al., 2003; Stadler et al., 2010), then it is clear that the trench-parallel strain rates are subordinate, being up to 40 times smaller than the convergence/bending related strain rates. Considering these relatively low trench-parallel strain rates in spherical geometry, implying low trench-parallel within-slab compressive stresses, it is here argued that the simplification of using Cartesian geometry does not have a significant effect on flat slab subduction formation and evolution.

\section{RESULTS}

\section{Flat Slab Subduction Relation With Subduction Zone Age and Width in Nature}

Figure 2 shows a compilation of the active subduction zones on Earth, either with or without flat slab subduction, and a number of subduction settings from the geological past for which flat slab subduction has been reported. Age since subduction initiation has been plotted against slab width. For those subduction zones without a flat slab (e.g., Scotia, Tonga-Kermadec-Hikurangi, Sunda, Nankai-Ryukyu, AleutiansAlaska, Hellenic), their current age and width (their trenchparallel extent) have been plotted. Note again that, following the definition outlined in the introduction, Nankai, Alaska and Cascadia are not counted as flat slab settings because their uppermost slab geometry is not defined by three slab hinges (as in Figure 1D with one concave-upward hinge) but only by two convex-upward hinges (as in Figure 1C). For those subduction zones with a flat slab (as in Figure 1D), their age and width have been plotted as it was at the onset of flat slab subduction. For all zones, their width at or close to the time of subduction initiation has also been plotted. The data generally plot in two clusters: (1) One cluster that plots toward the bottom left where most subduction zones are relatively narrow and young (e.g., Scotia, Manila, North Sulawesi, Nankai-Ryukyu, Puysegur), some are older but narrow (e.g., Hellenic, Cascadia, Lesser Antilles-Puerto Rico) and some are wide but young (e.g., Melanesia, Sunda, Northwest Pacific); and (2) Another cluster that is located toward the top right where subduction zones are both old and wide (e.g., South America). Those subduction zones that plot in the first 
domain all lack flat slab subduction as defined in Figure 1D (but note that low angle subduction as in Figure 1C can occur). Those subduction zones that plot in the second domain in the upper right region do have one or more segments that are characterized by flat slab subduction (e.g., segments $1 \mathrm{a}-\mathrm{c}$ ) but also segments that are not (e.g., segments $1 \mathrm{~d}-\mathrm{f})$.

\section{Geodynamic Model Results Geodynamic Model Evolution}

The four models all show subduction through trenchward subducting plate motion and through trench retreat. The first 35-40 Myr of the model runs are characterized by upper mantle subduction, which are followed by whole mantle subduction as the deepest part of the slab sinks into the lower mantle. Each of the models shows a similar, relatively steep, slab geometry during upper mantle subduction (Figure 4). During whole mantle subduction the different models develop variability in slab geometry.

The minimum slab dip angle in the depth range $100-200 \mathrm{~km}$ is tracked to identify flat slab subduction. This minimum dip angle is comparable for the four experiments in the early subduction stage and of the order $60-70^{\circ}$ (Figure 5A). Once the slab tip approaches the $660 \mathrm{~km}$ discontinuity at $\sim 35 \mathrm{Ma}$, the minimum dip angles for the different experiments start to diverge. All models show an overall, long-term, decrease in dip angle, but the magnitude of decrease depends on the slab width, with the largest decrease occurring for the widest slab. The narrow and intermediate-width slabs only show a moderate decrease in slab dip (with slab dip minima of 48 and $38^{\circ}$, respectively), while the wide and very wide slabs show a large decrease (with minima of 21 and $2^{\circ}$, respectively). For the wide slab model, slab flattening starts in a late stage at $\sim 171 \mathrm{Myr}$ (Figures 4C, 5A). Here, the start of slab flattening is defined as the onset of formation of the concave-upward slab hinge between $\sim 50-150 \mathrm{~km}$ depth in between the two convex-upward hinges. This slab flattening only occurs in the central part of the wide subduction zone (central $\sim 700 \mathrm{~km}$ ) and does not occur in segments closer toward the lateral slab edges. Indeed, the local slab dip angle near the lateral slab edges is consistently steeper than in the center with observed differences in dip angle up to $27^{\circ}$ toward the end of the model run (Figure 5B).

For the very wide slab model slab flattening starts at $\sim 134 \mathrm{Myr}$ and flat slab subduction starts at $\sim 150 \mathrm{Myr}$, lasting $\sim 25 \mathrm{Myr}$ (Figures 4D, 5), although briefly interrupted by a $\sim 4$ Myr period where the local dip angle exceeds $10^{\circ}$. Flat slab subduction is followed by approximately normal subduction with dip angles of $\sim 20-30^{\circ}$ until the end of the model run at $\sim 185$ Myr. Note again that flat slab subduction is defined as the moment when the flat slab segment downdip of the concave hinge has a dip angle $\leq 10^{\circ}$. Also note that time in the models depends on the scaling of viscosity and velocity. Average subduction rates in the models (3-4 cm/yr) are somewhat slower than the average present-day subduction rate on Earth $(5.5 \mathrm{~cm} / \mathrm{yr}$, Schellart et al., 2007). If we scale the average subduction velocities in the models to those in nature (implying a $\eta_{\mathrm{UM}-\mathrm{Max}}=2.7-3.6 \times 10^{20} \mathrm{~Pa}$ s in nature rather than $\eta_{U M-M a x}=5 \times 10^{20} \mathrm{~Pa} \mathrm{~s}$, with all values falling

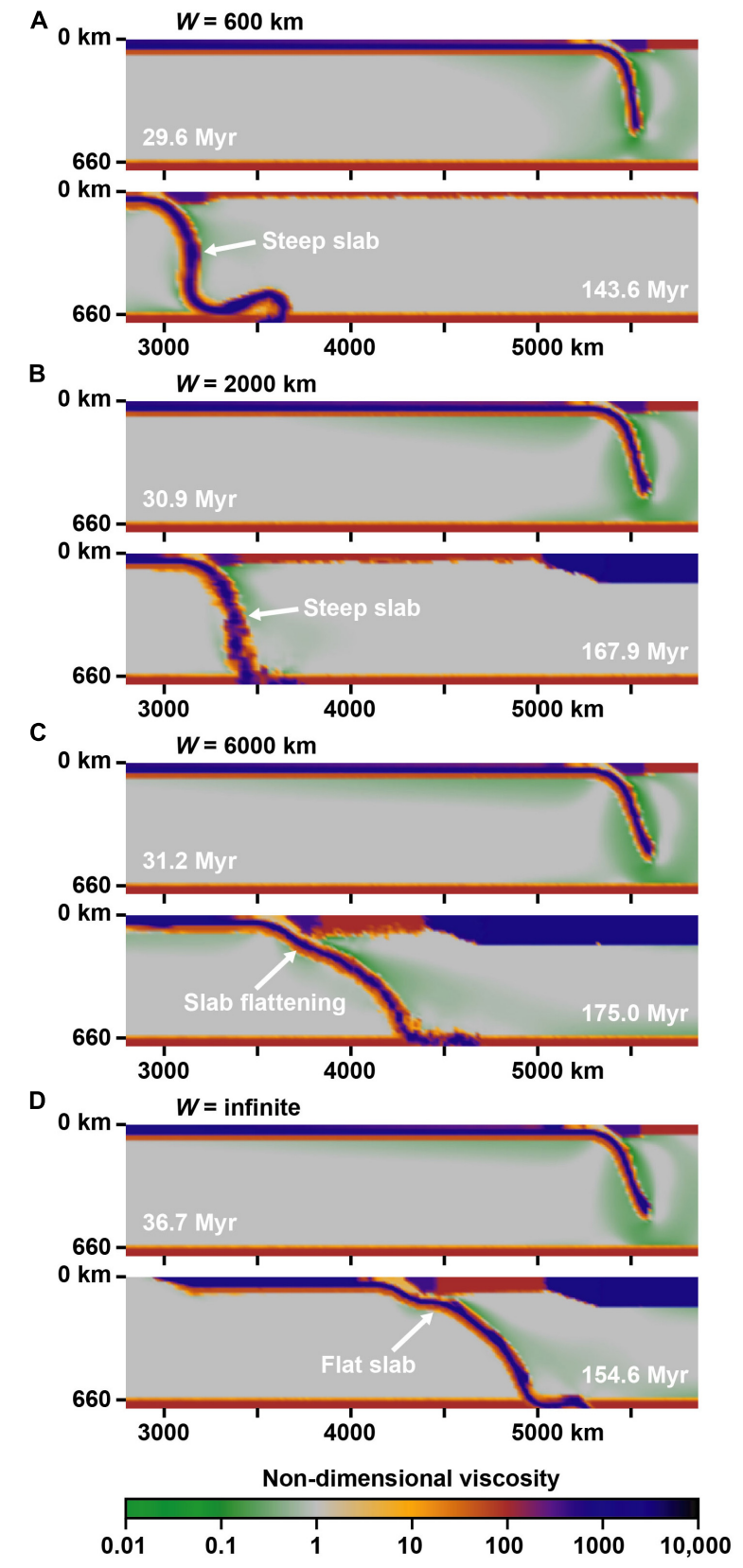

FIGURE 4 | Cross-sections through the center of four numerical subduction models with a different slab width showing two stages in the subduction process (early and late stage). (A) Narrow slab width model ( $W=600 \mathrm{~km})$ showing a steep upper mantle slab. (B) Intermediate-width slab model $(W=2000 \mathrm{~km}$ ) showing a steep upper mantle slab. (C) Wide slab model ( $W=6000 \mathrm{~km})$ showing upper mantle slab flattening in a late stage of subduction. (D) Very wide slab model ( $W=$ infinite, 2D set-up) showing flat slab subduction in a late stage of the model evolution. Colors indicate the non-dimensional effective viscosity field. Note that the somewhat fuzzy-blocky appearance of the slab in the lower part of the upper mantle in the bottom panels of $(\mathbf{B}, \mathbf{C})$ is the result of the implemented spatial adaptive mesh, which gives a lower resolution in the lower part of the upper mantle compared to the upper part, and the many times that repopulation of cells with particles was required to avoid the occurrence of empty cells. The high number of repopulation exercises, in particular for $W=2000$ and $W=6000$, caused the boundaries between different particle fields to become progressively fuzzier. 

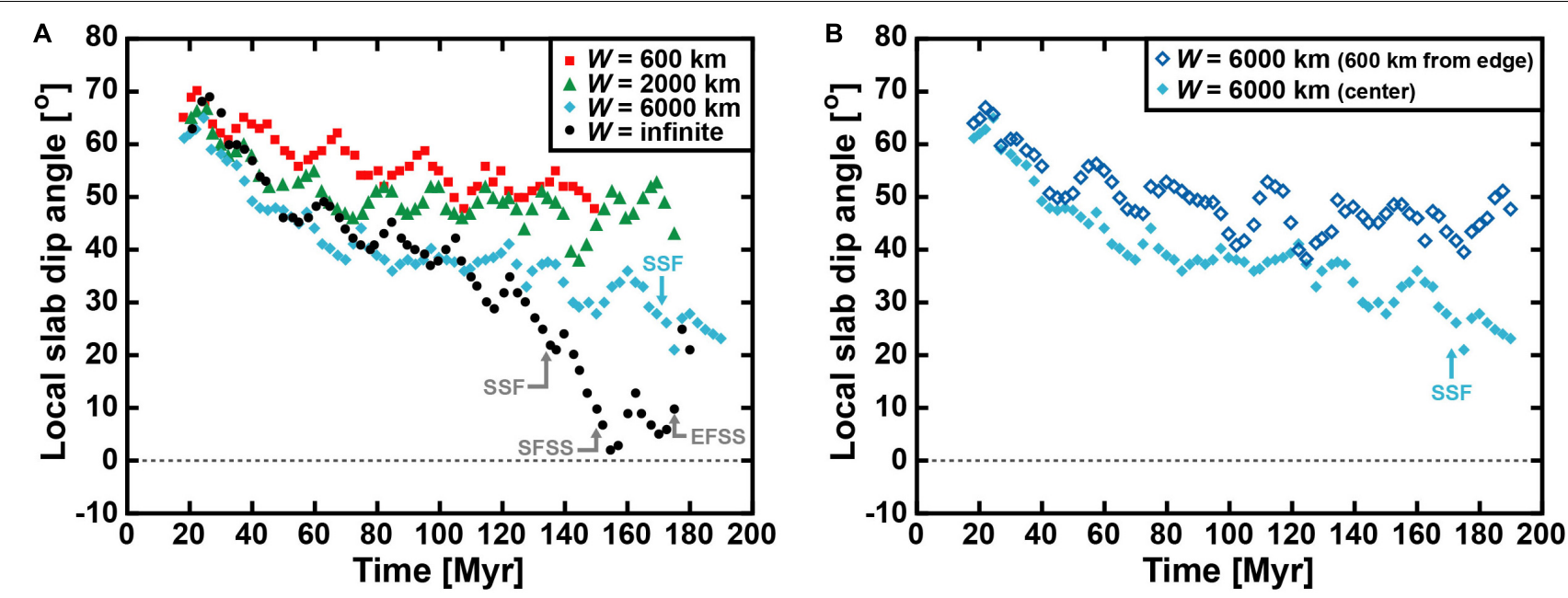

FIGURE 5 | Slab dip angle evolution of geodynamic models of progressive subduction in which the width (W) of the subduction zone is varied [narrow slab model with $W=600 \mathrm{~km}$, intermediate-width slab model with $W=2000 \mathrm{~km}$, wide slab model with $W=6000 \mathrm{~km}$, and very wide slab model with $W=$ infinite (2D set-up)]. The diagrams show the temporal evolution of the minimum slab dip angle for a local, 100-km-long, slab segment within the depth range $100-200 \mathrm{~km}$ to determine the flat slab subduction stage, which is defined as the time when the local slab dip is $\leq 10^{\circ}$. (A) Model results for the four different models for sections located in the center of the subduction zone. The narrow and intermediate-width slab models show no flat slab development. The wide slab model shows the onset of slab flattening in a late stage of the subduction process ( $\sim 171 \mathrm{Myr})$, with the development of a concave-upward hinge in the slab at $\sim 100-150 \mathrm{~km}$ depth. For the very wide slab model, the onset of slab flattening occurs earlier ( 134 Myr) and flat slab subduction occurs in a late stage of subduction at 150-175 Myr with a brief intermittent period of $\sim 4$ Myr where the local slab dip exceeds $10^{\circ}$. (B) Model results of the wide slab model for one section located at $600 \mathrm{~km}$ from the nearest lateral slab edge and one section through the center of the subduction zone (3000 km from the lateral slab edges). The section near the lateral slab edge retains a relatively steep slab dip angle and shows no sign of slab flattening, in contrast to the central section. SSF-Start of slab flattening; SFSS-Start of flat slab subduction; EFSS-End of flat slab subduction.

within the natural range), then flat slab subduction in the very wide slab model would be reached earlier, at $\sim 80-110$ Myr rather than $\sim 150$ Myr. But note that stresses are not affected by any rescaling of velocities.

\section{Stress in the Mantle Wedge and Sub-Slab Domain}

The vertical deviatoric normal stress $\left(\sigma_{Y Y}\right)$ in the mantle wedge and in the sub-slab domain has been plotted in Figure 6 for models W600, W6000 and W-infinite. For all models it can be observed that $\sigma_{Y Y}$ is mostly tensile in the mantle wedge near the top of the slab and compressive in the sub-slab domain near the base of the slab. Furthermore, $\sigma_{Y Y}$ values are relatively small for the narrow slab model (Figures 6A,B), in particular in an advanced stage of subduction. Here, $\sigma_{Y Y}$ is in the range -1.0 to $2.7 \mathrm{MPa}$ at the slab top from the tip of the wedge down to $200 \mathrm{~km}$ depth and in the range -1.2 to $0.4 \mathrm{MPa}$ at the base of the slab within the $100-200 \mathrm{~km}$ depth range. At an early stage of subduction $\sigma_{Y Y}$ values are somewhat higher, with a maximum of $\sim 4.0 \mathrm{MPa}$ (tension) at the slab top and a minimum of about $-1.9 \mathrm{MPa}$ (compression) at the base of the slab.

For the very wide slab model, $\sigma_{Y Y}$ values at an early subduction stage (Figure 6G) are comparable to those of the narrow slab model at the slab top with a maximum of $\sim 4.0 \mathrm{MPa}$ (tension), and are close to neutral (minimum of $-0.2 \mathrm{MPa}$ ) at the base of the slab above $200 \mathrm{~km}$ depth. At an advanced subduction stage, however, $\sigma_{Y Y}$ is generally much higher compared to the narrow slab model, with a maximum of $\sim 7.5 \mathrm{MPa}$ (tension) at the slab top and a minimum of about $-2.0 \mathrm{MPa}$ (compression) at the base (Figure $\mathbf{6 H}$ ). For the wide slab model W6000, the stresses in the central section (Figures 6E,F) are comparable to those of $\mathrm{W}$-infinite (Figures $\mathbf{6 G}, \mathbf{H}$ ), but the stresses in the section close to the lateral slab edge in a late stage of subduction (Figure 6D) are smaller.

\section{DISCUSSION}

\section{Mechanism of Flat Slab Subduction in the Geodynamic Models}

The major dip angle decrease for the wide and very wide slab models results from the large-scale whole mantle circulation they produce once the slabs enter the lower mantle. This flow drags the overriding plate trenchward, pushing the subduction hinge backward and forcing the overriding plate to thicken (Schellart, 2017) (forced hinge rollback or pushback, Figures 4C,D), while the slab itself resists rollback due to its great width (Schellart et al., 2007) and its partial anchoring in the lower mantle, thus attaining a progressively lower dip angle. The slab flattening that occurs in both models is facilitated by a relatively high effective suction force in the tip of the mantle wedge in a late stage of subduction. The very wide slab model with the $2 \mathrm{D}$ set-up, and thus an implied infinitely wide slab, develops the highest suction force in the tip that increases with time (Figures $\mathbf{6 G}, \mathbf{H}$ ), because lateral mantle inflow is absent, thereby facilitating flat slab formation. The wide slab model, despite its $6000 \mathrm{~km}$ width, allows for (minor) lateral mantle inflow around its lateral slab edges, reducing 

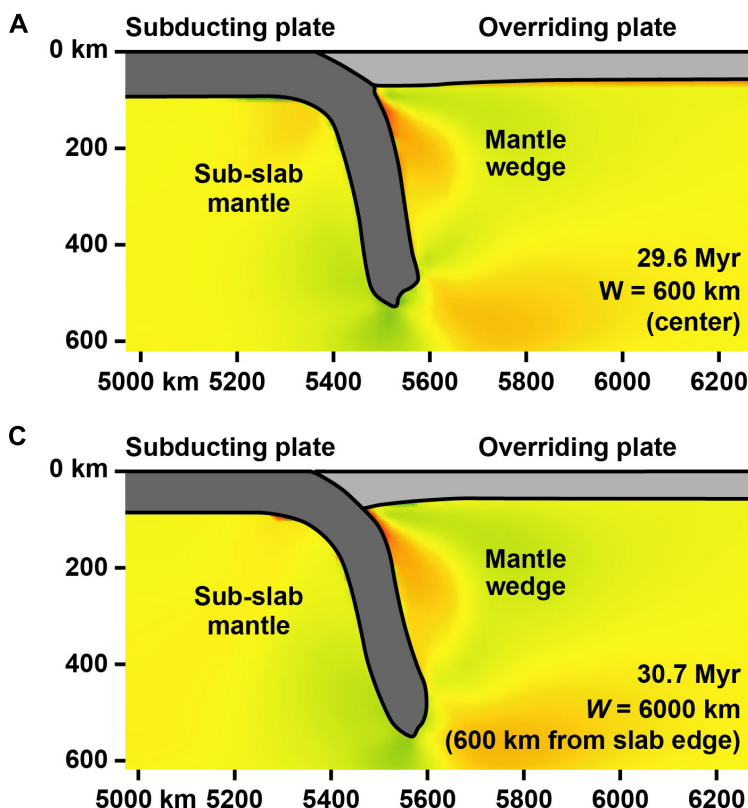

E Subducting plate

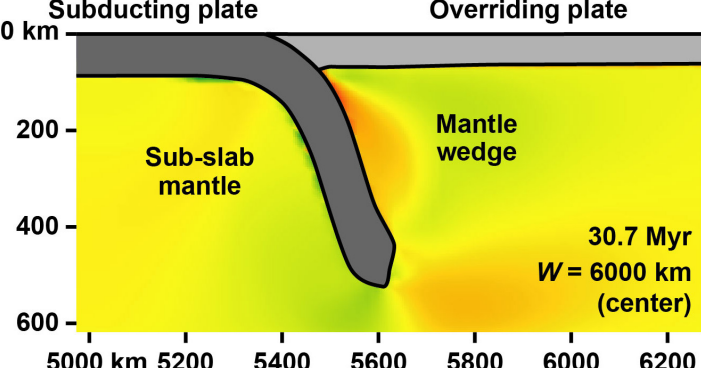

B

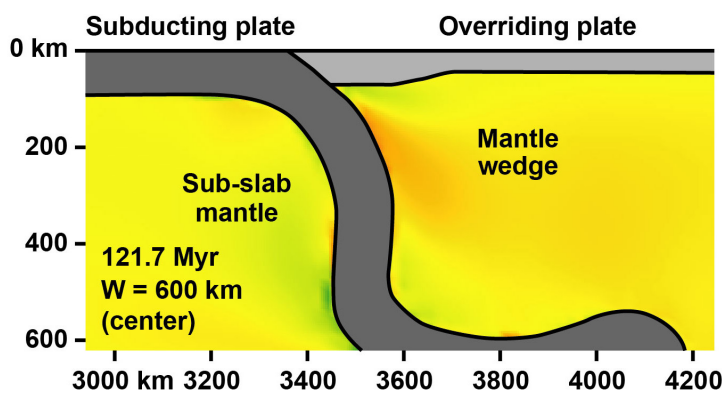

D

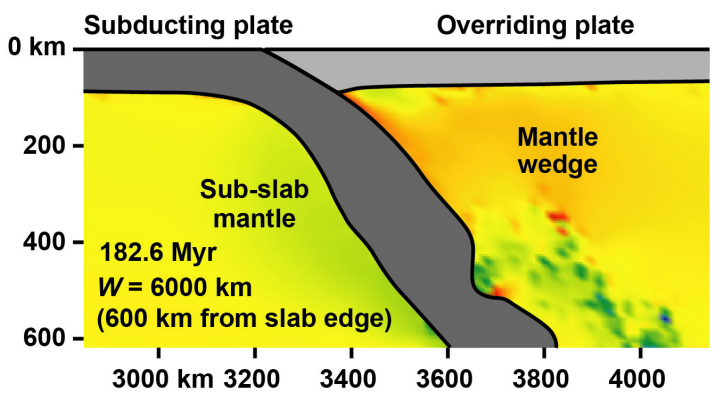

F Subducting plate

Overriding plate

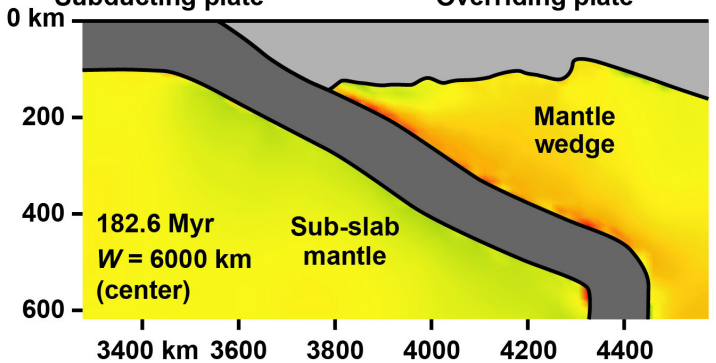

H

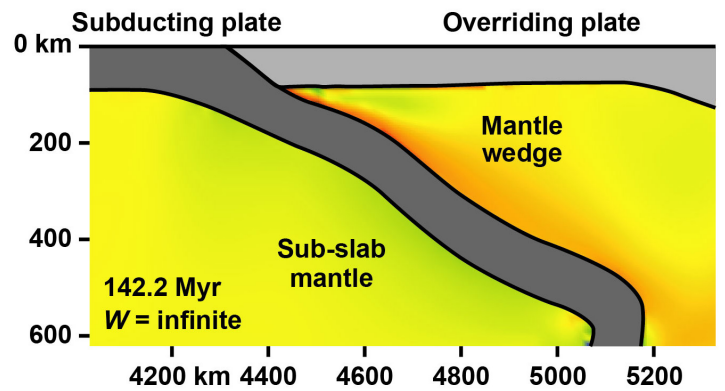

G

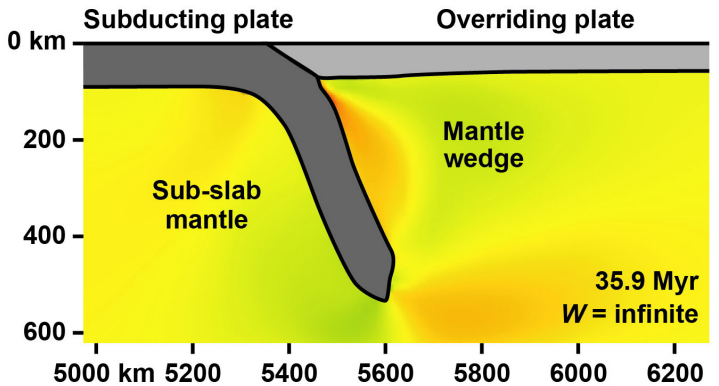

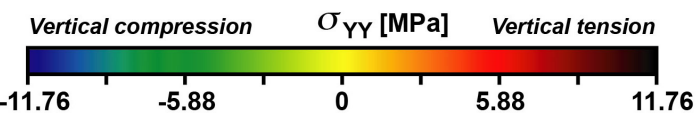

FIGURE 6 | Cross-sections through three numerical subduction models with a different slab width showing the vertical deviatoric normal stress ( $\sigma \mathrm{y}$ ) in the mantle wedge and sub-slab region at two stages during the subduction process (early and late stage). (A,B) Cross sections through the center of the narrow slab width model $(W=600 \mathrm{~km})$ showing relatively low stresses at all times. (C-F) Wide slab model $(W=6000 \mathrm{~km})$ with panels $\mathbf{C}$, $\mathbf{D}$ for a section located $600 \mathrm{~km}$ from the closest lateral slab edge and panels $\mathbf{E , F}$ for a section located in the center of the subduction zone ( $3000 \mathrm{~km}$ from the lateral slab edges). Low stresses are observed in the early subduction stage (C,E), intermediate stresses during a late stage near the lateral slab edge (D) and high stresses during a late stage in the center (F). $(\mathbf{G}, \mathbf{H})$ Very wide slab model $(W=$ infinite, 2D set-up) showing relatively low stresses in the early subduction stage $(\mathbf{G})$ but high stresses in a late subduction stage (H). Note that the short-wavelength structures in panel (D) (the dark green and red blobs at 300-600 km depth in the mantle wedge and just below the base of the overriding plate) are formed by slab material from the lateral slab edge that has been advected into the mantle wedge by the rollback-induced toroidal upper mantle return flow. This toroidal flow, which is directed from the sub-slab and around the lateral slab edge into the mantle wedge (e.g., Schellart et al., 2007), has curved and sheared the slab edge into the mantle wedge and has also sheared off small fragments from the slab edge. Additionally, a conseguence of the curvature is that the local trench orientation strikes at an oblique angle with respect to cross-section (D). The slab edge material has a higher viscosity than the ambient upper mantle material and therefore shows higher deviatoric stresses than the ambient upper mantle material. 
the wedge suction, and thus slab flattening develops more slowly (Figure 5A).

In case the slab is narrow or intermediate in width, slab rollback is directly driven by the negative buoyancy of the slab (slab-driven hinge rollback or pullback, Figures $4 \mathbf{4 A}, \mathbf{B}$ ) rather than being forced by the trenchward motion of the overriding plate, as is evident by the absence of overriding plate thickening but the presence of overriding plate thinning in these models. Rollback is facilitated by the presence of nearby lateral slab edges, which allow for efficient toroidal return flow from the sub-slab region toward the mantle wedge region (Dvorkin et al., 1993; Schellart et al., 2007), sustaining a relatively steep slab dip angle and lowering the suction in the mantle wedge. Indeed, $\sigma_{Y Y}$ just above the top surface of the slab is significantly lower for a narrow slab (Figure 6B), which has two nearby lateral slab edges, than for the center of a wide slab (Figure 6F), which has two distant lateral slab edges, and for an infinitely wide slab (Figure $6 \mathbf{H}$ ), which has no lateral slab edges. Furthermore, for trench segments of wide subduction zones located close to lateral slab edges, which only have one nearby lateral slab edge, $\sigma_{Y Y}$ is intermediate to that of narrow slabs and wide slabs (Figure 6). What is more, the vertical slab lifting force $\left(F_{\mathrm{L}}\right)$ that results from $\sigma_{\mathrm{YY}}$ is about an order of magnitude larger for a very wide slab than for a narrow slab. For W600, this lifting force, calculated from the tip of the mantle wedge down to $200 \mathrm{~km}$ depth, is $\sim 1.5 \times 10^{11} \mathrm{~N}$ per meter trench length. Here, $\sim 66 \%$ results from the vertical suction at the top of the slab, while $\sim 34 \%$ results from vertical compressive stresses at the base of the slab. For the very wide slab model the vertical lifting force is $\sim 1.4 \times 10^{12} \mathrm{~N}$ per meter trench length, with $\sim 76 \%$ resulting from the vertical suction at the slab top and $\sim 24 \%$ from the vertical compressive stress at the base of the slab. $F_{\mathrm{L}}$ is also more significant for wide slabs when compared with the negative buoyancy force $\left(F_{\mathrm{Bu}}\right)$ of the same slab segment for which the lifting force has been calculated. For the very wide slab model $F_{\mathrm{L}} / F_{\mathrm{Bu}}=\sim 8.7 \%$, while for the narrow slab model $F_{\mathrm{L}} / F_{\mathrm{Bu}}=\sim 1.7 \%$.

The proposed important role of subduction zone size and age, and the proposed mechanism of slab-induced whole-mantle return flow in driving trenchward overriding plate motion, slab dip angle decrease and eventually slab flattening at wide subduction zones, can be reconciled with earlier modeling studies. Indeed, a number of earlier modeling works have advocated the important role of forced trench retreat (e.g., van Hunen et al., 2004; Manea et al., 2012), large wedge suction (e.g., Tovish et al., 1978; van Hunen et al., 2004; Manea et al., 2012; Rodríguez-González et al., 2012) and a thick overriding plate (e.g., Rodríguez-González et al., 2012) or far-field thick craton in the overriding plate (e.g., Manea et al., 2012; O’Driscoll et al., 2012; Taramón et al., 2015) in promoting flat slab subduction. The current work shows that, in a buoyancy-driven environment, forced trench retreat, large wedge suction and a thick overriding plate will develop in a wide subduction zone setting after a long period of subduction (of the order $100 \mathrm{Myr}$ ) once the slab tip has reached a significant depth in the lower mantle. The current work also shows that such features will not develop in a narrow or intermediate-width subduction zone setting, or close to lateral slab edges.
The mechanism for flat slab generation as proposed above requires a slab in nature to behave as a strong entity that is generally continuous from the surface to the lower mantle without major holes or tears in the upper mantle part of the slab. Indeed, it is generally thought that slab tearing can facilitate the collapse and removal of a flat slab (e.g., Hu and Liu, 2016; Schepers et al., 2017). For a strong and continuous slab, this requires natural slabs to have a greater viscosity than the ambient upper mantle, which is generally thought to be the case with slabs that are, on average, about 140-510 times (Ribe, 2010) or 100-700 times (Schellart, 2008) more viscous than the ambient mantle. The current models adopt comparable average viscosity ratios and slab deformation is accommodated through stretching, thickening, bending and buckling, not by slab tearing, thereby facilitating flat slab subduction. Another requirement is for slabs to be continuous from the surface down to the lower mantle, which is the case for a number of slabs in nature that include flat slab segments, as implied by mantle tomography studies. In particular, several tomography studies indicate that part of the Nazca slab subducting below South America continues down to $\sim 2400 \mathrm{~km}$ (e.g., van der Meer et al., 2018), and that part of the Cocos slab subducting along the Mexico-Central America subduction zone continues down to $\sim 2600-2800 \mathrm{~km}$ (e.g., Boschman et al., 2018).

\section{Present-Day Flat Slabs in the Eastern Pacific}

Flat slab subduction occurs in the Eastern Pacific in Peru, Central Chile, and Mexico and the proposed flat slab mechanism, involving a wide subduction zone $(\geq \sim 6000 \mathrm{~km})$ and prolonged $(>\sim 80-110$ Myr) subduction, applies to these examples (Figure 2). Indeed, they formed at the Farallon/South American subduction zone at a time when it had been active for a long period (since the Middle Triassic-Early Jurassic) (Burchfiel and Davis, 1975; Coira et al., 1982; Boschman et al., 2018) and when it was extremely wide $(7000-13,000 \mathrm{~km})$. The Altiplano flat slab that formed in the central Andes at $\sim 35 \mathrm{Ma}$ and terminated at $\sim 25 \mathrm{Ma}$ (Ramos and Folguera, 2009) can also be explained in this manner. Although the Mexico flat slab is currently part of an intermediate-width subduction zone (Mexico-Central America), at the time when this flat slab formed at $30-25 \mathrm{Ma}$, as implied by the inboard migration of arc magmatism (Ferrari et al., 1999; Morán-Zenteno et al., 1999; Kim et al., 2010), the subduction zone was very wide $(\sim 11,000 \mathrm{~km})$ (Table $\mathbf{1})$.

There are also several subduction segments of the South American subduction zone and Mexico-Central America subduction zone that do not contain a flat slab, including the Colombia, Northern Chile, Southern Chile and Central America segments. This observation implies that an old and wide subduction zone is a requirement for flat slab subduction to occur, but it is not a guarantee that a flat slab will always be present. The observation is consistent with the geodynamic modeling results, which show that for the very wide slab model flat slab subduction is a transient phenomenon, for this model lasting some $25 \mathrm{Myr}$, and is preceded and succeeded by normal subduction. The transient nature of flat slab subduction is at 
least partly explained by the periodic folding of the slab at the $660 \mathrm{~km}$ discontinuity and the initiation of flat slab subduction is likely triggered by a new slab folding phase. Such folding is also responsible for the periodic dip angle changes (Schellart, 2017) that characterize each model (Figure 5). In nature, flat slab subduction at an old and wide subduction zone could also be triggered by a slab folding phase at the $660 \mathrm{~km}$ discontinuity, or it could be triggered by another process such as the initiation of subduction of an aseismic ridge or plateau.

\section{Past Flat Slab Subduction Latest Cretaceous-Early Cenozoic Flat Slab Subduction in Western North America}

Flat slab subduction has been proposed for Western North America to explain the eastward migration of the magmatic arc and the eastward migration of the deformation front during cordilleran mountain building in the Late Cretaceous and Early Cenozoic (Henderson et al., 1984; DeCelles, 2004). Formation of the flat slab has been ascribed to the trenchward motion of the overriding North American plate and the subduction of aseismic ridges or oceanic plateaus (Henderson et al., 1984; Liu and Currie, 2016). The current work implies that flat slab subduction would not have been possible in the first place were it not for the extreme width $(\sim 12,000 \mathrm{~km})$ and longevity $(\sim 110 \mathrm{Myr})$ of the subduction zone (Figure 2), and the large separation of the flat slab segment from lateral slab edges (Table 1).

\section{Mid Triassic-Early Jurassic Flat Slab Subduction in South China}

A model of flat slab subduction has been proposed to explain the broad intracontinental Mesozoic orogen in South China and the postorogenic magmatism in the region ( $\mathrm{Li}$ and $\mathrm{Li}, 2007$ ), with flat slab subduction starting in the mid Triassic $(\sim 230 \mathrm{Ma})$ (Li and $\mathrm{Li}, 2007$ ) along a subduction zone in the paleo Western Pacific. Reconstructions indicate that the subduction zone has been active since the mid Carboniferous (330 Ma) (Domeier and Torsvik, 2014) or Middle Devonian-Early Carboniferous (390$356 \mathrm{Ma}$ ) (Collins, 2003; Domeier and Torsvik, 2014). As such, the subduction zone had been active for 100-160 Myr when the flat slab developed along a subduction zone that was likely very wide (Figure 2 and Table 1), which is consistent with the proposed mechanism.

\section{Absence of Present-Day Flat Slabs in the Western Pacific and Elsewhere}

The general absence of current flat slabs (i.e., with a slab geometry as in Figure 1D) in the Western Pacific, Indian Ocean, Atlantic Ocean, and Mediterranean can be explained by the lack of at least one of two crucial ingredients, namely subduction zone longevity and large slab width (Figure 2). There are three large subduction zones $(W \geq 4000 \mathrm{~km})$ in these regions, Sunda, Northwest Pacific and Melanesia (Schellart et al., 2007), but Sunda has been active only since the Middle Eocene (Hall, 2012), Northwest Pacific came into existence only after the Izu-Bonin-Mariana segment formed in the Early Eocene (Arculus et al., 2015), while Melanesia only formed in the Miocene (Hall, 2002; Table 2). Apart from these three subduction zones, the remaining ones in the Western Pacific, Atlantic, Indian Ocean and Mediterranean all have small or intermediate widths (Schellart et al., 2007). The lack of subduction zone longevity and/or large width did not allow for a significant decrease in slab dip angle (Figure 5) nor did it enhance suction forces (Figures 6A-C,E), thereby preventing subduction zones in these regions to form a flat slab. The lack of subduction zone longevity and/or large width also prevented those Western Pacific subduction zones subducting an aseismic ridge or plateau (e.g., d'Entrecasteaux Ridge at the New Hebrides subduction segment, MarcusNecker Ridge at the Mariana-Bonin segment) to form a flat slab. This implies that buoyant ridge/plateau subduction is not sufficient on its own to cause flat slab subduction, in agreement with earlier work on Nazca Ridge subduction (Antonijevic et al., 2015). It is also consistent with recent geodynamic experiments of buoyancy-driven subduction with an aseismic ridge, indicating that subduction of a large ridge (e.g., Carnegie Ridge or Nazca Ridge) reduces the slab dip angle in the shallow part of the upper mantle by a mere $\sim 10^{\circ}$ and does not produce flat slab subduction on its own (Flórez-Rodríguez et al., 2019).

\section{CONCLUSION}

The observational constraints (Figure 2) and models (Figures 46) imply that flat slab subduction dominantly initiates at wide subduction zones $(\geq \sim 6000 \mathrm{~km})$ and only after a prolonged period of subduction ( $\geq \sim 80-110 \mathrm{Myr}$ ). This finding is consistent with earlier works advocating the role of forced trench retreat, large wedge suction and a thick or cratonic overriding plate in promoting flat slab subduction (e.g., van Hunen et al., 2004; Manea et al., 2012, 2017; O’Driscoll et al., 2012; Rodríguez-González et al., 2012; Taramón et al., 2015; Schepers et al., 2017), because only in the center of wide subduction zones do forced trench retreat and overriding plate thickening develop in a late subduction stage, and is the effective wedge suction high. The conceptual model works for the proposed Laramide flat slab in western North America (Henderson et al., 1984; DeCelles, 2004), the Early Mesozoic South China flat slab ( $\mathrm{Li}$ and $\mathrm{Li}, 2007$ ), and the current flat slabs in the Eastern Pacific, as they developed at old and wide subduction zones (Figure 2). The finding can also explain the absence of present-day flat slabs in the Western Pacific, Indian Ocean, Atlantic Ocean and Mediterranean, because subduction zones here are either relatively young $(<\sim 80-$ $110 \mathrm{Ma}$ ), less than $\sim 6000 \mathrm{~km}$ wide, or both. Subduction of a buoyant aseismic ridge or plateau in these regions will not induce flat slab subduction, as slabs in these regions will not have had sufficient time to reduce their dip angle at shallow depth and/or will not have a significant mantle wedge suction force due to the limited slab width. It thereby solves a longstanding debate on the lack of spatial correlation between ridge subduction and flat slab subduction in regions outside the Eastern Pacific. 


\section{DATA AVAILABILITY STATEMENT}

All data and methods necessary to understand, evaluate, replicate, and build upon the reported research are presented in this article.

\section{AUTHOR CONTRIBUTIONS}

The author confirms being the sole contributor of this work and has approved it for publication.

\section{FUNDING}

This work has been funded by a Vici Fellowship (016.VICI.170.110) from the Dutch National Science Foundation

\section{REFERENCES}

Advokaat, E. L., Bongers, M. L. M., Rudyawan, A., BouDagher-Fadel, M. K., Langereis, C. G., and van Hinsbergen, D. J. J. (2018). Early Cretaceous origin of the Woyla arc (Sumatra, Indonesia) on the Australian plate. Earth Planet. Sci. Lett. 498, 348-361. doi: 10.1016/j.epsl.2018.07.001

Antonijevic, S. K., Wagner, L. S., Kumar, A., Beck, S. L., Long, M. D., Zandt, G., et al. (2015). The role of ridges in the formation and longevity of flat slabs. Nature 524, 212-215. doi: 10.1038/nature14648

Arculus, R. J., Ishizuka, O., Bogus, K. A., Gurnis, M., Hickey-Vargas, R., Aljahdali, M. H., et al. (2015). A record of spontaneous subduction initiation in the Izu-Bonin-Mariana arc. Nat. Geosci. 8, 728-733. doi: 10.1038/NGEO 2515

Arredondo, K. M., and Billen, M. I. (2016). The effects of phase transitions and compositional layering in two-dimensional kinematic models of subduction. J. Geodyn. 100, 159-174. doi: 10.1016/j.jog.2016.05.009

Artyushkov, E. V. (1983). Geodynamics. Amsterdam: Elsevier.

Betts, P. G., Giles, D., Foden, J., Schaefer, B. F., Mark, G., Pankhurst, M. J., et al. (2009). Mesoproterozoic plume-modified orogenesis in eastern Precambrian Australia. Tectonics 28:TC3006. doi: 10.1029/2008TC002325

Boschman, L. M., van Hinsbergen, D. J. J., Kimbrough, D. L., Langereis, C. G., and Spakman, W. (2018). The dynamic history of 220 million years of subduction below Mexico: a correlation between slab geometry and overriding plate deformation based on geology, paleomagnetism, and seismic tomography. Geochem. Geophys. Geosyst. 19, 4649-4672. doi: 10.1029/2018GC00 7739

Boschman, L. M., van Hinsbergen, D. J. J., Torsvik, T. H., Spakman, W., and Pindell, J. L. (2014). Kinematic reconstruction of the Caribbean region since the Early Jurassic. Earth Sci. Rev. 138, 102-136. doi: 10.1016/j.earscirev.2014. 08.007

Burchfiel, B. C., and Davis, G. A. (1975). Nature and controls of cordilleran orogenesis, western United States: extensions of an earlier synthesis. Am. J. Sci. 275, 363-396.

Burke, K. (1988). Tectonic evolution of the Caribbean. Ann. Rev. Earth Planet. Sci. 16, 201-230. doi: 10.1146/annurev.ea.16.050188.001221

Centeno-García, E. (2017). Mesozoic tectono-magmatic evolution of Mexico: an overview. Ore Geol. Rev. 81, 1035-1052. doi: 10.1016/j.oregeorev.2016. 10.010

Chen, Y. W., Wu, J., and Suppe, J. (2019). Southward propagation of Nazca subduction along the Andes. Nature 565, 441-447. doi: 10.1038/s41586-0180860-861

Chen, Z., Schellart, W. P., Strak, V., and Duarte, J. C. (2016). Does subductioninduced mantle flow drive backarc extension? Earth Planet. Sci. Lett. 441, 200-210. doi: 10.1016/j.epsl.2016.02.027

Coira, B., Davidson, J., Mpodozis, C., and Ramos, V. (1982). Tectonic and magmatic evolution of the Andes of northern Argentina and Chile. Earth Sci. Rev. 18, 303-332. doi: 10.1016/0012-8252(82)90042-3
(NWO), and has been supported by computational resources from the NCI National Facility in Australia through the National Computational Merit Allocation Scheme (project qk0).

\section{ACKNOWLEDGMENTS}

Discussions with and/or comments from Vincent Strak, Joao Duarte, Marc-Andre Gutscher, Douwe van Hinsbergen, Filipe Rosas, and Mélanie Gérault on subduction dynamics, subduction geology and flat slab subduction are greatly appreciated. I would like to thank the two reviewers for their constructive comments and suggestions, which have improved the contents and clarity of this paper. I would also like to thank Louis Moresi, Mirko Velic, Julian Giordani, John Mansour, and Owen Kaluza for technical support with, and development of, the Underworld code.

Collins, W. J. (2003). Slab pull, mantle convection, and Pangaean assembly and dispersal. Earth Planet. Sci. Lett. 205, 225-237. doi: 10.1016/s0012-821x(02) 01043-9

Copeland, P., Currie, C. A., Lawton, T. F., and Murphy, M. A. (2017). Location, location, location: the variable lifespan of the Laramide orogeny. Geology 45, 223-226. doi: 10.1130/G38810.1

DeCelles, P. G. (2004). Late Jurassic to Eocene evolution of the Cordilleran thrust belt and foreland basin system Western U.S.A. Am. J. Sci. 304, 105-168. doi: 10.2475/ajs.304.2.105

Deschamps, A., and Lallemand, S. (2002). The West Philippine Basin: an Eocene to early Oligocene back arc basin opened between two opposed subduction zones. J. Geophys. Res. 107:2322. doi: 10.1029/2001JB001706

Dickinson, W. R., and Snyder, W. S. (1978). Plate tectonics of the Laramide orogeny. Geol. Soc. Am. Mem. 151, 355-366. doi: 10.1130/mem151-p355

Dilek, Y., and Sandvol, E. (2009). "Seismic structure, crustal architecture and tectonic evolution of the Anatolian-African Plate Boundary and the Cenozoic Orogenic Belts in the Eastern Mediterranean Region," in Ancient Orogens and Modern Analogues, eds J. B. Murphy, J. D. Keppie, and A. J. Hynes (Bath: The Geological Society of London), 127-160. doi: 10.1144/SP327.8

Domeier, M., and Torsvik, T. H. (2014). Plate tectonics in the Late Paleozoic. Geosci. Front. 5, 303-350. doi: 10.1016/j.gsf.2014.01.002

Dvorkin, J., Nur, A., Mavko, G., and Ben-Avraham, Z. (1993). Narrow subducting slabs and the origin of backarc basins. Tectonophysics 227, 63-79. doi: 10.1016/ 0040-1951(93)90087-z

Eagles, G., and Jokat, W. (2014). Tectonic reconstructions for paleobathymetry in Drake Passage. Tectonophysics 611, 28-50. doi: 10.1016/j.tecto.2013.11.021

Ferrari, L., López-Martínez, M., Aguirre-Díaz, G., and Carrasco-Núñez, G. (1999). Space-time patterns of Cenozoic arc volcanism in central Mexico: from the Sierra Madre Occidental to the Mexican Volcanic Belt. Geology 27, 303-306.

Flórez-Rodríguez, A. G., Schellart, W. P., and Strak, V. (2019). Impact of aseismic ridges on subduction systems: insights from analog modeling. J. Geophys. Res. Solid Earth 124, 5951-5969. doi: 10.1029/2019JB017488

Ganguly, J., Freed, A. M., and Saxena, S. K. (2009). Density profiles of oceanic slabs and surrounding mantle: integrated thermodynamic and thermal modeling, and implications for the fate of slabs at the $660 \mathrm{~km}$ discontinuity. Phys. Earth Planet. Inter. 172, 257-267. doi: 10.1016/j.pepi.2008.10.005

Gordon, R. G., and Jurdy, D. M. (1986). Cenozoic global plate motions. J. Geophys. Res. 91, 12389-12406. doi: 10.1029/jb091ib12p12389

Gutscher, M. A., Spakman, W., Bijwaard, H., and Engdahl, E. R. (2000). Geodynamics of flat subduction: seismicity and tomographic constraints from the Andean margin. Tectonics 19, 814-833. doi: 10.1029/1999tc001152

Hall, R. (2002). Cenozoic geological and plate tectonic evolution of SE Asia and the SW Pacific; computer-based reconstructions, model and animations. J. Asian Earth Sci. 20, 353-431. doi: 10.1016/s1367-9120(01)00069-4

Hall, R. (2012). Late Jurassic-Cenozoic reconstructions of the Indonesian region and the Indian Ocean. Tectonophysics. 570-571, 1-41. doi: 10.1016/j.tecto.2012. 04.021 
Hastie, A. R., Mitchell, S. F., Treloar, P. J., Kerr, A. C., Neill, I., and Barfod, D. N. (2013). Geochemical components in a Cretaceous island arc: the Th/La$\left(\mathrm{Ce} / \mathrm{Ce}^{*}\right)_{\mathrm{Nd}}$ diagram and implications for subduction initiation in the interAmerican region. Lithos 162, 57-69. doi: 10.1016/j.lithos.2012.12.001

Hayes, G. P., Wald, D. J., and Johnson, R. L. (2012). Slab1.0: a three-dimensional model of global subduction zone geometries. J. Geophys. Res. 117:B01302. doi: 10.1029/2011JB008524

Henderson, L. J., Gordon, R. G., and Engebretson, D. C. (1984). Mesozoic aseismic ridges on the Farallon plate and southward migration of shallow subduction during the Laramide orogeny. Tectonics 3, 121-132. doi: 10.1029/ tc003i002p00121

Hu, J., and Liu, L. (2016). Abnormal seismological and magmatic processes controlled by the tearing South American flat slabs. Earth Planet. Sci. Lett. 450, 40-51. doi: 10.1016/j.epsl.2016.06.019

Hu, J., Liu, L., Hermosillo, A., and Zhou, Q. (2016). Simulation of Late Cenozoic South American flat-slab subduction using geodynamic models with data assimilation. Earth Planet. Sci. Lett. 438, 1-13. doi: 10.1016/j.epsl.2016.01.011

Ishizuka, O., Tani, K., Reagan, M. K., Kanayama, K., Umino, S., Harigane, Y., et al. (2011). The timescales of subduction initiation and subsequent evolution of an oceanic island arc. Earth Planet. Sci. Lett. 306, 229-240. doi: 10.1016/j.epsl.2011. 04.006

Jarrard, R. D. (1986). Relations among subduction parameters. Rev. Geophys. 24, $217-284$.

Jicha, B. R., Scholl, D. W., Singer, B. S., and Yogodzinski, G. M. (2006). Revised age of Aleutian Island Arc formation implies high rate of magma production. Geology 34, 661-664. doi: 10.1130/G22433.1

Kay, S. M., and Abbruzzi, J. M. (1996). Magmatic evidence for Neogene lithospheric evolution of the Central Andean "flat-slab" between $30^{\circ} \mathrm{S}$ and $32^{\circ} \mathrm{S}$. Tectonophysics 259, 15-28. doi: 10.1016/0040-1951(96)00032-7

Kim, Y., Clayton, R. W., and Jackson, J. M. (2010). Geometry and seismic properties of the subducting cocos plate in Central Mexico. J. Geophys. Res. 115:B06310. doi: 10.1029/2009JB006942

Kincaid, C., and Olson, P. (1987). An experimental study of subduction and slab migration. J. Geophys. Res. 92, 812-813.

Kreemer, C., Holt, W. E., and Haines, A. J. (2003). An integrated global model of present-day plate motions and plate boundary deformation. Geophys. J. Inter. 154, 8-34. doi: 10.1046/j.1365-246x.2003.01917.x

Lallemand, S., Font, Y., Bijwaard, H., and Kao, H. (2001). New insights on 3$D$ plates interaction near Taiwan from tomography and tectonic implications. Tectonophysics 335, 229-253. doi: 10.1016/s0040-1951(01)00071-3

Lallemand, S., Heuret, A., and Boutelier, D. (2005). On the relationship between slab dip, back-arc stress, upper plate absolute motion, and crustal nature in subduction zones. Geochem. Geophys. Geosyst. 6:Q09006. doi: 10.1029/ 2005GC000917

Larter, R. D., Vanneste, L. E., Morris, P., and Smythe, D. K. (2003). "Structure and tectonic evolution of the South Sandwich arc," in Intra-Oceanic Subduction Systems: Tectonic and Magmatic Processes, eds R. D. Larter, and P. T. Leat (Bath: The Geological Society of London), 255-284. doi: 10.1144/gsl.sp.2003.219.01.13

LeBrun, J. F., Lamarche, G., and Collot, J. Y. (2003). Subduction initiation at a strike-slip plate boundary: the Cenozoic Pacific-Australian plate boundary, south of New Zealand. J. Geophys. Res. 108:2453. doi: 10.1029/2002JB002041

Li, C. F., Xu, X., Lin, J., Sun, Z., Zhu, J., Yao, Y., et al. (2014). Ages and magnetic structures of the South China Sea constrained by deep tow magnetic surveys and IODP Expedition 349. Geochem. Geophys. Geosyst. 15, 4958-4983. doi: $10.1002 / 2014 \mathrm{GC} 005567$

Li, Z. X., and Li, X. H. (2007). Formation of the $1300-\mathrm{km}$-wide intracontinental orogen and postorogenic magmatic province in Mesozoic South China: a flat-slab subduction model. Geology 35, 179-182. doi: 10.1130/G23193A.1

Liu, L., Gurnis, M., Seton, M., Saleeby, J., Muller, R. D., and Jackson, J. M. (2010). The role of oceanic plateau subduction in the Laramide orogeny. Nat. Geosci. 3, 353-357. doi: 10.1038/NGEO829

Liu, S., and Currie, C. A. (2016). Farallon plate dynamics prior to the Laramide orogeny: numerical models of flat subduction. Tectonophysics 666, 33-47. doi: 10.1016/j.tecto.2015.10.010

Lonergan, L., and White, N. (1997). Origin of the Betic-Rif mountain belt. Tectonics 16, 504-522. doi: 10.1029/96tc03937

Lonsdale, P. (2005). Creation of the Cocos and Nazca plates by fission of the Farallon plate. Tectonophysics 404, 237-264. doi: 10.1016/j.tecto.2005.05.011
Mackaman-Lofland, C., Horton, B. K., Fuentes, F., Constenius, K. N., and Stockli, D. F. (2019). Mesozoic to Cenozoic retroarc basin evolution during changes in tectonic regime, southern Central Andes $\left(31-33^{\circ} \mathrm{S}\right)$ : insights from zircon U-Pb geochronology. J. South Am. Earth Sci. 89, 299-318. doi: 10.1016/j.jsames.2018. 10.004

Mackwell, S. J., Bai, Q., and Kohlstedt, D. L. (1990). Rheology of olivine and the strength of the lithosphere. Geophys. Res. Lett. 17, 9-12. doi: 10.1029/ gl017i001p00009

Maloney, K. T., Clarke, G. L., Klepeis, K. A., and Quevedo, L. (2013). The Late Jurassic to present evolution of the Andean margin: drivers and the geological record. Tectonics 32, 1049-1065. doi: 10.1002/tect.20067

Manea, V. C., Manea, M., Ferrari, L., Orozco-Esquivel, T., Valenzuela, R. W., Husker, A., et al. (2017). A review of the geodynamic evolution of flat slab subduction in Mexico, Peru, and Chile. Tectonophysics 695, 27-52. doi: 10.1016/ j.tecto.2016.11.037

Manea, V. C., Pérez-Gussinyé, M., and Manea, M. (2012). Chilean flat slab subduction controlled by overriding plate thickness and trench rollback. Geology 40, 35-38. doi: 10.1130/G32543.1

Meffre, S., Falloon, T. J., Crawford, T. J., Hoernle, K., Hauff, F., Duncan, R. A., et al. (2012). Basalts erupted along the Tongan fore arc during subduction initiation: evidence from geochronology of dredged rocks from the Tonga fore arc and trench. Geochem. Geophys. Geosyst. 13:Q12003. doi: 10.1029/2012GC004335

Mériaux, C. A., Mériaux, A. S., Schellart, W. P., Duarte, J. C., Duarte, S. S., and Chen, Z. (2016). Mantle plumes in the vicinity of subduction zones. Earth Planet. Sci. Lett. 454, 166-177. doi: 10.1016/j.epsl.2016.09.001

Morán-Zenteno, D. J., Tolson, G., Martínez-Serrano, R. G., Martiny, B., Schaaf, P., Silva-Romo, G., et al. (1999). Tertiary arc-magmatism of the Sierra Madre del Sur, Mexico, and its transition to the volcanic activity of the trans-Mexican Volcanic Belt. J. South Am. Earth Sci. 12, 513-535. doi: 10.1016/s0895-9811(99) 00036-x

Moresi, L., Quenette, S., Lemiale, V., Mériaux, C., Appelbe, B., and Mühlhaus, H. B. (2007). Computational approaches to studying non-linear dynamics of the crust and mantle. Phys. Earth Planet. Inter. 163, 69-82. doi: 10.1016/j.pepi.2007.0 6.009

Müller, R. D., Seton, M., Zahirovic, S., Williams, S. E., Matthews, K. J., Wright, N. M., et al. (2016). Ocean basin evolution and global-scale plate reorganization events since Pangea breakup. Ann. Rev. Earth Planet. Sci. 44, 107-138. doi: 10.1146/annurev-earth-060115-12211

O'Driscoll, L. J., Richards, M. A., and Humphreys, E. D. (2012). Nazca-South America interactions and the late Eocene-late Oligocene flat-slab episode in the Central Andes. Tectonics 31:TC2013. doi: 10.1029/2011TC003036

Ohta, Y., Freymueller, J. T., Hreinsdóttir, S., and Suito, H. (2006). A large slow slip event and the depth of the seismogenic zone in the south central Alaska subduction zone. Earth Planet. Sci. Lett. 247, 108-116. doi: 10.1016/j.epsl.2006. 05.013

Phillips, K., and Clayton, R. W. (2014). Structure of the subduction transition region from seismic array data in southern Peru. Geophys. J. Inter. 196, 18891905. doi: $10.1093 /$ gji/ggt504

Pilger, R. H. (1981). Plate reconstructions, aseismic ridges, and low-angle subduction beneath the Andes. Geol. Soc. Am. Bull. 92, 448-456.

Pindell, J., Kennan, L., Stanek, K. P., Maresch, W. V., and Draper, G. (2006). Foundations of Gulf of Mexico and Caribbean evolution: eight controversies resolved. Geol. Acta 4, 303-341.

Ramos, V. A., and Folguera, A. (2009). "Andean flat-slab subduction through time," in Ancient Orogens and Modern Analogues, eds J. B. Murphy, J. D. Keppie, and A. J. Hynes (Bath: The Geological Society of London), 31-54. doi: $10.1144 /$ SP 327.3

Ranalli, G. (1995). Rheology of the Earth, 2nd Edn, London: Chapman and Hall.

Ribe, N. M. (2010). Bending mechanics and mode selection in free subduction: a thin-sheet analysis. Geophys. J. Inter. 180, 559-576. doi: 10.1111/j.1365-246X. 2009.04460.x

Richards, S., Holm, R., and Barber, G. (2011). When slabs collide: a tectonic assessment of deep earthquakes in the Tonga-Vanuatu region. Geology 39, 787-790. doi: 10.1130/G31937.1

Rodríguez-González, J., Negredo, A. M., and Billen, M. I. (2012). The role of the overriding plate thermal state on slab dip variability and on the occurrence of flat subduction. Geochem. Geophys. Geosyst. 13:Q01002. doi: 10.1029/ 2011GC003859 
Rosenbaum, G., Giles, D., Saxon, M., Betts, P. G., Weinberg, R. F., and Duboz, C. (2005). Subduction of the Nazca Ridge and the Inca Plateau: insights into the formation of ore deposits in Peru. Earth Planet. Sci. Lett. 239, 18-32. doi: $10.1016 /$ j.epsl.2005.08.003

Rosenbaum, G., Lister, G. S., and Duboz, C. (2002). Reconstruction of the tectonic evolution of the Western Mediterranean since the Oligocene. J. Virt. Explor. 8, 107-130.

Sarma, D. S., Jafri, S. H., Fletcher, I. R., and McNaughton, N. J. (2010). Constraints on the tectonic setting of the Andaman ophiolites, Bay of Bengal, India, from SHRIMP U-Pb zircon geochronology of plagiogranite. J. Geol. 118, 691-697. doi: $10.1086 / 656354$

Schellart, W. P. (2008). Kinematics and flow patterns in deep mantle and upper mantle subduction models: influence of the mantle depth and slab to mantle viscosity ratio. Geochem. Geophys. Geosyst. 9:Q03014. doi: 10.1029/ 2007GC001656

Schellart, W. P. (2017). Andean mountain building and magmatic arc migration driven by subduction-induced whole mantle flow. Nat. Commun. 8:2010. doi: 10.1038/s41467-017-01847-z

Schellart, W. P., Freeman, J., Stegman, D. R., Moresi, L., and May, D. (2007). Evolution and diversity of subduction zones controlled by slab width. Nature 446, 308-311. doi: 10.1038/nature05615

Schellart, W. P., Jessell, M. W., and Lister, G. S. (2003). Asymmetric deformation in the backarc region of the Kuril arc, northwest Pacific: new insights from analogue modeling. Tectonics 22:1047. doi: 10.1029/2002TC001473

Schellart, W. P., Lister, G. S., and Toy, V. G. (2006). A Late Cretaceous and Cenozoic reconstruction of the Southwest Pacific region: tectonics controlled by subduction and slab rollback processes. Earth Sci. Rev. 76, 191-233. doi: 10.1016/j.earscirev.2006.01.002

Schellart, W. P., and Spakman, W. (2012). Mantle constraints on the plate tectonic evolution of the Tonga-Kermadec-Hikurangi subduction zone and the South Fiji Basin. Austr. J. Earth Sci. 59, 933-952. doi: 10.1080/08120099.2012.679692

Schellart, W. P., Stegman, D. R., Farrington, R. J., Freeman, J., and Moresi, L. (2010). Cenozoic tectonics of western North America controlled by evolving width of Farallon slab. Science 329, 316-319. doi: 10.1126/science.1190366

Schepers, G., van Hinsbergen, D. J. J., Spakman, W., Kosters, M. E., Boschman, L. M., and McQuarrie, N. (2017). South-American plate advance and forced Andean trench retreat as drivers for transient flat subduction episodes. Nat. Commun. 8:15249. doi: 10.1038/ncomms15249

Scheuber, E., Bogdanic, T., Jensen, A., and Reutter, K. J. (1994). "Tectonic development of the North Chilean Andes in relation to plate convergence and magmatism since the Jurassic," in Tectonics of the Southern Central Andes, eds K.-J. Reutter, E. Scheuber, and P. J. Wigger (Berlin: Springer), 121-139. doi: 10.1007/978-3-642-77353-2_9

Scholl, D. W., Vallier, T. L., and Stevenson, A. J. (1986). Terrane accretion, production, and continental growth: a perspective based on the origin and tectonic fate of the Aleutian-Bering Sea region. Geology 14, 43-47.

Sdrolias, M., Roest, W. R., and Muller, R. D. (2004). An expression of Philippine Sea plate rotation: the Parece Vela and Shikoku Basins. Tectonophysics 394, 69-86. doi: 10.1016/j.tecto.2004.07.061

Séranne, M. (1999). "The gulf of Lion continental margin (NW Mediterranean) revisited by IBS: an overview," in The Mediterranean Basins: Tertiary Extension Within the Alpine Orogen, eds B. Durand, L. Jolivet, F. Horváth, and M. Séranne (London: Geological Society), 15-36. doi: 10.1144/gsl.sp.1999.156.01.03

Seton, M., Müller, R. D., Zahirovic, S., Gaina, C., Torsvik, T., Shephard, G., et al. (2012). Global continental and ocean basin reconstructions since $200 \mathrm{Ma}$. Earth Sci. Rev. 113, 212-270. doi: 10.1016/j.earscirev.2012.03.002

Skinner, S. M., and Clayton, R. W. (2011). An evaluation of proposed mechanisms of slab flattening in central Mexico. Pure Appl. Geophys. 168, 1461-1474. doi: 10.1007/s00024-010-0200-203

Skinner, S. M., and Clayton, R. W. (2013). The lack of correlation between flat slabs and bathymetric impactors in South America. Earth Planet. Sci. Lett. 37, 1-5. doi: 10.1016/j.epsl.2013.04.013
Spakman, W., and Hall, R. (2010). Surface deformation and slab-mantle interaction during Banda arc subduction rollback. Nat. Geosci. 3, 562-566. doi: 10.1038/NGEO917

Stadler, G., Gurnis, M., Burstedde, C., Wilcox, L. C., Alisic, L., and Ghattas, O. (2010). The dynamics of plate tectonics and mantle flow: from local to global scales. Science 329, 1033-1038. doi: 10.1126/science.1191223

Stegman, D. R., Freeman, J., Schellart, W. P., Moresi, L., and May, D. (2006). Influence of trench width on subduction hinge retreat rates in 3-D models of slab rollback. Geochem. Geophys. Geosyst. 7:Q03012. doi: 10.1029/ 2005GC001056

Taramón, J. M., Rodríguez-González, J., Negredo, A. M., and Billen, M. I. (2015). Influence of cratonic lithosphere on the formation and evolution of flat slabs: insights from 3-D time-dependent modeling. Geochem. Geophys. Geosyst. 16, 2933-2948. doi: 10.1002/2015GC005940

Torii, Y., and Yoshioka, S. (2007). Physical conditions producing slab stagnation: constraints of the Clapeyron slope, mantle viscosity, trench retreat, and dip angles. Tectonophysics 445, 200-209. doi: 10.1016/j.tecto.2007.0 8.003

Tovish, A., Schubert, G., and Luyendyk, B. P. (1978). Mantle flow pressure and the angle of subduction: non-Newtonian corner flows. J. Geophys. Res. 83, 5892-5898. doi: 10.1029/jb083ib12p05892

van de Lagemaat, S. H. A., van Hinsbergen, D. J. J., Boschman, L. M., Kamp, P. J. J., and Spakman, W. (2018). Southwest Pacific absolute plate kinematic reconstruction reveals major Cenozoic Tonga-Kermadec slab dragging. Tectonics 37, 2647-2674. doi: 10.1029/2017TC004901

van der Meer, D. G., van Hinsbergen, D. J. J., and Spakman, W. (2018). Atlas of the underworld: slab remnants in the mantle, their sinking history, and a new outlook on lower mantle viscosity. Tectonophysics $723,309-448$. doi: 10.1016/j.tecto.2017.10.004

van Hinsbergen, D. J. J., Hafkenscheid, E., Spakman, W., Meulenkamp, J. E., and Wortel, R. (2005). Nappe stacking resulting from subduction of oceanic and continental lithosphere below Greece. Geology 33, 325-328.

van Hinsbergen, D. J. J., Vissers, R. L. M., and Spakman, W. (2014). Origin and consequences of Western Mediterranean subduction, rollback, and slab segmentation. Tectonics 33, 393-419. doi: 10.1002/tect.20125

van Hunen, J., Van Den Berg, A. P., and Vlaar, N. J. (2002). On the role of subducting oceanic plateaus in the development of shallow flat subduction. Tectonophysics 352, 317-333. doi: 10.1016/s0040-1951(02)00263-9

van Hunen, J., van den Berg, A. P., and Vlaar, N. J. (2004). Various mechanisms to induce present-day shallow flat subduction and implications for the younger earth: a numerical parameter study. Phys. Earth Planet. Inter. 146, 179-194. doi: $10.1016 /$ j.pepi.2003.07.027

Vásquez, P., Glodny, J., Franz, G., Frei, D., and Romer, R. L. (2011). Early Mesozoic plutonism of the Cordillera de la Costa $\left(34^{\circ}-37^{\circ} \mathrm{S}\right)$, Chile: constraints on the onset of the Andean orogeny. J. Geol. 119, 159-184. doi: 10.1086/658296

Vérard, C., Flores, K., and Stampfli, G. (2012). Geodynamic reconstructions of the South America-Antarctica plate system. J. Geodyn. 53, 43-60. doi: 10.1016/j. jog.2011.07.007

Wortel, M. J. R., and Spakman, W. (2000). Subduction and slab detachment in the Mediterranean-Carpathian region. Science 290, 1910-1917. doi: 10.1126/ science.290.5498.1910

Conflict of Interest: The author declares that the research was conducted in the absence of any commercial or financial relationships that could be construed as a potential conflict of interest.

Copyright (C) 2020 Schellart. This is an open-access article distributed under the terms of the Creative Commons Attribution License (CC BY). The use, distribution or reproduction in other forums is permitted, provided the original author(s) and the copyright owner(s) are credited and that the original publication in this journal is cited, in accordance with accepted academic practice. No use, distribution or reproduction is permitted which does not comply with these terms. 


\section{APPENDIX}

\section{Justification for Data Selection and Uncertainties Associated With the Data}

There are uncertainties associated with the data presented in Tables 1, 2 that are used as a basis for Figure 2. For the presentday slab width values listed in Table 2, the uncertainties are relatively small, in general less than $5-10 \%$, which will therefore have no discernable impact on the data distribution as shown in Figure 2A. Uncertainties with estimated slab width values for the geological past will be larger and are generally hard to quantify, as they mostly result from differences in plate tectonic configurations in the published literature. For the relatively narrow subduction zones listed in Table 2 (numbers 6-14) the uncertainties can be up to several hundred kilometers, but this will have no discernable impact on the general distribution of data points in Figure 2A. For the slab width data of the other subduction zones, which have a moderate to very large width (numbers 1-5 and 15-22) there are larger uncertainties. These subduction zones generally also have a larger associated uncertainty in subduction zone age, or a subduction zone age that is more controversial. Below, each of these subduction zones will be briefly discussed and a justification for the choice of subduction zone age and width is provided.

\section{South American Subduction Zone (Points 1a-f and 3 in Figure 2 and Tables 1, 2)}

The age of the South American subduction zone has long been interpreted as very old, around $200 \mathrm{Ma}$, and thus dating from the Late Triassic/Early Jurassic (e.g., Coira et al., 1982; Vásquez et al., 2011; Maloney et al., 2013). This old age has very recently been contested by Chen et al. (2019), who argue for an $80 \mathrm{Ma}$ subduction zone in the north, becoming progressively younger southward. The young age for the South American subduction zone proposed by Chen et al. (2019) is in contradiction with geological data showing a continuous arc magmatic record from the Jurassic to the present $(\sim 200-0 \mathrm{Ma})$, such as reported for northern Chile (Scheuber et al., 1994). It is also in contradiction with seismic tomographic data presented in van der Meer et al. (2018), which show a continuous slab from the trench down to $2400 \pm 200 \mathrm{~km}$ depth in the Peru segment of the South American subduction zone, which they interpreted as subduction being active from 200-173 Ma (Jurassic) to the present. Recent work on sedimentary systems in the retroarc and arc region in the southern Central Andes also imply continuous subduction activity since the Late Triassic/Early Jurassic (e.g., MackamanLofland et al., 2019). Based on these different lines of evidence, I adopt an old age ( 200 Ma) for the South American subduction zone.

Tectonic reconstructions show that at $\sim 200 \mathrm{Ma}$ the entire western margin of the South American continent was an eastdipping subduction zone and generally also show it to be continuous with the Mexico-Central America segment (e.g., Seton et al., 2012). This gives a subduction zone width of the order $11,000 \pm 1000 \mathrm{~km}$.
For data points $1 \mathrm{a}, 1 \mathrm{~b}$ and $1 \mathrm{c}$, the flat slab formed at $\sim 4, \sim 8$, and $\sim 20 \mathrm{Ma}$ and so formed when the Nazca plate had already separated from the Cocos plate, which occurred at $\sim 23 \mathrm{Ma}$ (Lonsdale, 2005). Thus the width of the subduction zone was roughly the north-south length of the western margin of South America, which is of the order $7000 \mathrm{~km}$. The flat slab for data point 3 formed at $\sim 35 \mathrm{Ma}$, so before Nazca-Cocos separation, and so the slab width at that time was roughly the sum of the South American subduction zone width and the width of the Baja California-Mexico-Central America segment.

\section{Mexico-Central America Subduction Zone (Points 2a} and $2 \mathrm{~b}$ in Figure 2 and Tables 1, 2)

The Mexican flat slab formed at $\sim 30-25 \mathrm{Ma}$ (Ferrari et al., 1999; Morán-Zenteno et al., 1999; Kim et al., 2010), and the Cocos spreading ridge separating the Cocos plate from the Nazca plate formed only at $\sim 23 \mathrm{Ma}$ (Lonsdale, 2005). Thus, the Nazca + Cocos single plate subducted eastward as one very large slab, most likely along one continuous subduction zone at $30-25 \mathrm{Ma}$ that would be $\sim 10,500-12,000 \mathrm{~km}$ wide (some $7000 \mathrm{~km}$ for the South American subduction segment and some $3000-5000 \mathrm{~km}$ for the Mexico-Central America segment). This is consistent with tectonic reconstructions (e.g., Gordon and Jurdy, 1986; Seton et al., 2012; Müller et al., 2016).

Recent work indicates that at least the Mexico-Central America subduction segment has been active for a very long time. Indeed, according to Boschman et al. (2018) there is a continuous record of subduction since $220 \mathrm{Ma}$ along the MexicoCentral America subduction zone, as indicated by a continuous slab geometry from the surface down to $2500-2800 \mathrm{~km}$ depth in seismic tomography models. According to van der Meer et al. (2018) this old subduction zone had a large lateral extent, stretching from the Cocos ridge in the south to the Mendocino triple junction in the north (their page 351), which would imply a subduction zone extent of $\sim 5800 \mathrm{~km}$. This width is used as a lower limit of the slab width of the subduction zone during its formation. As an upper limit the reconstruction of Seton et al. (2012) is used, which shows a continuous subduction zone from Mexico in the north to Patagonia in the south at $200 \mathrm{Ma}$, which would thus imply an $\sim 11,000 \mathrm{~km}$ wide subduction zone at a time close to its inception.

Another reconstruction, that of Müller et al. (2016), shows a different tectonic setting in the Mexico-Central AmericaCaribbean region with a subduction flip and $\sim$ west-dipping subduction at $\sim 130-90 \mathrm{Ma}$, which would not be consistent with the current work and that of Seton et al. (2012). The recent work of Boschman et al. (2018), however, can be used to refute the proposed tectonic scenario from Müller et al. (2016), as it shows a long and continuous subducted slab, from the surface down to $\sim 2500-2800 \mathrm{~km}$ depth, which implies long-lived continuous east-dipping subduction along the Central AmericaMexico subduction zone.

\section{South China Subduction Zone (Point 4 in Figure 2 and Table 1)}

The age of inception and the width of the South China subduction zone have been derived from the reconstruction papers of 
Collins (2003) and Domeier and Torsvik (2014). It is clear that there are large uncertainties associated with the estimated age and width, because we are concerned with subduction that was active in the Paleozoic and Triassic, and flat slab subduction that started in the Triassic ( $\mathrm{Li}$ and Li, 2007). Despite these large uncertainties, the results are consistent with the conceptual model proposed in the paper (Figure 2A).

\section{Farallon Subduction Zone (Points 5 and 15 in Figure 2 and Tables 1, 2)}

The Farallon subduction zone is generally thought to have been a very large, east-dipping subduction zone along the west coast of the Americas that subducted the Farallon oceanic plate during part of the Mesozoic and the Early Cenozoic (Burchfiel and Davis, 1975; Gordon and Jurdy, 1986; DeCelles, 2004). Earlier work indicates that the subduction zone is very old and formed in the Triassic or Jurassic (160-210 Ma) (Burchfiel and Davis, 1975; DeCelles, 2004), and relatively recent reconstructions imply a comparably old age (e.g., Seton et al., 2012). Such reconstructions also imply a very large subduction zone extent during subduction zone infancy exceeding 10,000 km (Seton et al., 2012). Only at 45-30 Ma, significantly after the inception of Farallon flat slab formation at $\sim 85-65 \mathrm{Ma}$ (Henderson et al., 1984; Liu et al., 2010; Copeland et al., 2017), do reconstructions show that the Farallon plate, slab and subduction zone segment due to the formation of slab windows (Gordon and Jurdy, 1986; Schellart et al., 2010), resulting in the formation of a relatively small Farallon/Juan de Fuca plate subducting along the Cascadia subduction zone and a much larger Nazca-Cocos plate.

\section{Nankai-Ryukyu Subduction Zone (Point 16 in Figure 2 and Table 2)}

The Nankai-Ryukyu subduction zone likely formed in the earliest Miocene $(\sim 18 \mathrm{Ma})$ through subduction of the Philippine Sea plate below Eurasia (Lallemand et al., 2001). When the subduction zone formed, it was initially narrower $(\sim 1600 \mathrm{~km})$ and from $\sim 8 \mathrm{Ma}$ it grew southwestward to include the southern Ryukyu subduction segment (Lallemand et al., 2001).

\section{Lesser Antilles-Puerto Rico Subduction Zone (Point 17 in Figure 2 and Table 2)}

The age and the subduction zone width at the time of subduction zone formation of the Lesser Antilles subduction zone are somewhat controversial. The minimum age of $45 \mathrm{Ma}$ is based on the oldest ages of Lesser Antilles arc magmatism (Burke, 1988). There is a $\sim 50 \mathrm{Ma}$ age based on a reconstruction of Boschman et al. (2014), a 71-94 Ma age based on reported ages of arc magmatism from Hispaniola (Hastie et al., 2013), and a $\sim 120 \mathrm{Ma}$ age as argued and shown in a reconstruction in Pindell et al. (2006). van der Meer et al. (2018) estimate the age using tomography and geological data and propose subduction initiation at 45-55 Ma for the lesser Antilles. Estimates of subduction zone width at subduction initiation vary significantly, as shown in tectonic reconstructions, including $\sim 1400 \mathrm{~km}$ (Boschman et al., 2014) and $\sim 3300 \mathrm{~km}$ (Pindell et al., 2006). Considering the controversy, the average is taken for both the subduction zone age and width.

\section{Tonga-Kermadec-Hikurangi Subduction Zone (Point 18 in Figure 2 and Table 2)}

The subduction zone age and the width at the time of the TongaKermadec-Hikurangi subduction zone formation are somewhat controversial as well. The minimum age is generally based on the oldest ages of fore-arc magmatism in the Tonga arc (49$51 \mathrm{Ma}$ ) (Meffre et al., 2012) and reconstructions that adhere to this relatively young formation age imply that the subduction zone width during initiation was relatively small $(1800 \pm 800 \mathrm{~km})$ (Meffre et al., 2012). More recently, an even younger minimum age has been suggested for the formation of the subduction zone ( $\sim 30 \mathrm{Ma}$ ) based on the termination of the New Caledonia subduction zone around that time (van de Lagemaat et al., 2018). This very young age is not likely, though, as backarc spreading in the North Loyalty Basin and South Fiji Basin was already active before $30 \mathrm{Ma}$. Reconstructions from Schellart et al. (2006) show a subduction zone that was already active at $90 \mathrm{Ma}$, as implied by convergence between the Australian plate and the Pacific plate, with a large width $(\sim 5000 \mathrm{~km})$ that incorporates the TongaKermadec-Hikurangi segment and the Vitiaz-Solomon segment. Due to the uncertainty and controversy regarding the slab width at subduction initiation and time of subduction initiation, an average between that of Meffre et al. (2012) and Schellart et al. (2006) has been taken.

\section{Aleutians-Alaska Subduction Zone (Point 19 in Figure 2 and Table 2)}

It is generally agreed upon that the Aleutians-Alaska subduction zone formed sometime in the Early Cenozoic as based on ages of the oldest arc magmatic rocks in the Aleutian Islands, with an older age of $\sim 55$ Ma suggested earlier (Scholl et al., 1986) and a younger age ( $\sim 46 \mathrm{Ma})$ suggested more recently (Jicha et al., 2006). The younger age is here taken as the best estimate of the true age. The Aleutians segment is thought to have formed in an intra-oceanic setting and was limited in the west by the Shirshov Ridge, after which the subduction zone grew westward to form a cusp with the Kuril-Kamchatka arc (Schellart et al., 2003). Hence, the subduction zone had a smaller width (by 500 km) at subduction initiation than its present width.

\section{Melanesia Subduction Zone (Point 20 in Figure 2 and Table 2)}

It is generally agreed upon that the Melanesia subduction zone is very young and formed in the Late Cenozoic, around 10-15 Ma (Hall, 2002; Schellart et al., 2006; Richards et al., 2011). In the short time since $15 \mathrm{Ma}$ it has grown to a relatively wide subduction zone with a width of $\sim 4400 \mathrm{~km}$ (Schellart et al., 2007).

\section{Northwest Pacific Subduction Zone (Points 21, 21a, and $21 \mathrm{~b}$ in Figure 2 and Table 2)}

The width of the Northwest Pacific subduction zone, or Kamchatka-Kuril-Japan-Izu-Bonin-Mariana subduction zone, is very large, $\sim 6550 \mathrm{~km}$, but it formed rather recently due to the conjoining of the Izu-Bonin-Mariana segment and the Kamchatka-Kuril-Japan segment. The former segment formed around $52 \mathrm{Ma}$, as implied by dated forearc magmatic rocks 
(Ishizuka et al., 2011), while the latter segment formed at $\sim 60 \mathrm{Ma}$, after accretion of the Okhotsk terrane to Eurasia (Schellart et al., 2003). A maximum age of subduction zone formation is thus $52 \mathrm{Ma}$ (assuming that the two segments conjoined immediately, which is not very likely due to the difference in strike of the two segments at that time), while a minimum age of subduction zone formation is based on a reconstruction of Sdrolias et al. (2004), who show that the two segments connected at $\sim 25 \mathrm{Ma}$.

\section{Sunda Subduction Zone (Points 22, 22a, and 22b in Figure 2 and Table 2)}

The width of the slab subducting at the Sunda subduction zone is very large, $\sim 7850 \mathrm{~km}$, as it includes the BurmaAndaman segment, the Sumatra-Java-Bali-Nusa segment and the
Timor-Banda segment (Schellart et al., 2007). These individual segments, however, formed at different times. The Andaman subduction segment likely started around 94 Ma based on suprasubduction-zone ophiolites of this age, as dated by Sarma et al. (2010) and interpreted as such by Advokaat et al. (2018), but this subduction segment is only $\sim 1400 \mathrm{~km}$ wide $(\sim 3150 \mathrm{~km}$ if one includes the Burma segment). The central segment of the Sunda subduction zone (Sumatra-Java-Bali-Nusa), which is $\sim 3300 \mathrm{~km}$ wide, formed at $\sim 50-45 \mathrm{Ma}$ (Hall, 2012), while the easternmost segment (Banda segment), which is $\sim 1400 \mathrm{~km}$ wide, formed only at $\sim 15 \mathrm{Ma}$ (Spakman and Hall, 2010). So from $\sim 94-50 \mathrm{Ma}$ the slab was $\sim 3150 \mathrm{~km}$ wide, from $\sim 50-15 \mathrm{Ma}$ it was $\sim 6450 \mathrm{~km}$ wide, and from $\sim 15-0 \mathrm{Ma}$ it was $\sim 7850 \mathrm{~km}$ wide. As such, it acquired its large width only very recently. 